Fall 2011

\title{
The New Super-Charged Pat (Power of Appointment Trust)
}

Wendy G. Gerzog

University of Baltimore School of Law, wgerzog@ubalt.edu

Follow this and additional works at: http://scholarworks.law.ubalt.edu/all_fac

Part of the Estates and Trusts Commons, Family Law Commons, Taxation-Federal Commons, Taxation-Federal Estate and Gift Commons, and the Tax Law Commons

\section{Recommended Citation}

The New Super-Charged Pat (Power of Appointment Trust), 48 Hous. L. Rev. 507 (2011)

This Article is brought to you for free and open access by the Faculty Scholarship at ScholarWorks@University of Baltimore School of Law. It has been accepted for inclusion in All Faculty Scholarship by an authorized administrator of ScholarWorks@University of Baltimore School of Law. For more information, please contact snolan@ubalt.edu. 


\title{
ARTICLE
}

\section{THE NEW SUPER-CHARGED PAT (POWER OF APPOINTMENT TRUST)}

\author{
Wendy C. Gerzog*
}

TABLE OF CONTENTS

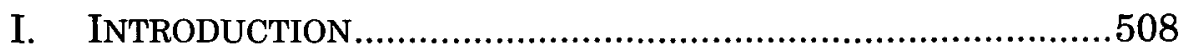

II. CRITIQUING THE QTIP ................................................512

III. DEFERRAL IN THE CONTEXT OF THE MARITAL

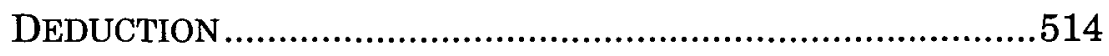

IV. THE QTIP TRUST: MINIMAL SPOUSAL OWNERSHIP .............517

V. THE FLEXIBILITY OF THE QTIP TRUST ............................520

A. A Partial QTIP Election ...........................................520

B. A Reverse QTIP Election ..........................................522

C. A State-Only QTIP Election ......................................524

D. A Clayton Contingent QTIP Election.........................525

E. The Marital-Charitable Trust Combination ...............526

VI. OUTRIGHT BEQUEST OR A TRUST? ....................................528

A. Outright Transfer....................................................528

1. Benefits of Outright Transfer................................528

2. Comparison with the Flexibility of a QTIP Trust ....528

B. A Trust ..................................................................530

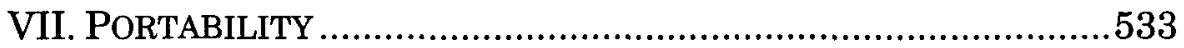

* Professor, University of Baltimore School of Law. I would like to thank the attendees at the Critical Tax Theory Conference, held at St. Louis University School of Law on April 10, 2010, for their helpful comments. 
VIII. DISCLAIMER OR SUPER-CHARGED PAT?

X. SUPERCHARGE THE PAT

XII. CONCLUSION

\section{INTRODUCTION}

The estate tax, together with the generation-skipping transfer (GST) tax, is intended to impose a tax on the transfer of property at each generation. ${ }^{1}$ While controversial, the purpose of transfer taxes is to break up wealth concentrations ${ }^{2}$ and to collect at least a modicum of revenue. ${ }^{3}$ The marital deduction, currently unlimited in amount, ${ }^{4}$ is the largest destroyer of that revenue stream. $^{5}$ Revenue is collected, for all but the extremely

1. Martha Britton Eller, Which Estates Are Affected by the Federal Estate Tax?: An Examination of the Filing Population for Year-of-Death 2001, STAT. INCOME BULL., Summer 2005, at 1, available at http:/www.irs.gov/pub/irs-soi/01esyod.pdf.

2. See, e.g., Joseph M. Dodge, Replacing the Estate Tax with a Reimagined Accessions Tax, 60 HASTINGS L.J. 997, 1002 (2009) (discussing the rationale behind transfer taxes); James R. Repetti, Democracy, Taxes, and Wealth, 76 N.Y.U. L. REV. 825, 849-51 (2001) (evaluating possible justifications for the estate tax).

3. Despite the increased exemption amounts, the correspondingly fewer taxpayers paying the estate tax, and the decreased tax rates, the revenue derived from the estate tax has not significantly diminished. Between 2001 and 2005 , for example, when the exemption increased from $\$ 675,000$ to $\$ 1.5$ million, the maximum tax rate decreased from $55 \%$ to $47 \%$, and the number of estate tax returns filed declined "by more than 58[\%], from 108,071 in 2001 to 45,070 in 2005 ," the revenue from those returns did not significantly diminish. The revenue derived in 2005 from the estate tax amounted to $\$ 21.7$ billion, as compared with the revenue raised in 2001 , which was $\$ 23.5$ billion. Brian G. Raub, Recent Changes in the Estate Tax Level and Filing Population, STAT. Income BULL., Summer 2007, at 114, 114-16, available at http://www.irs.gov/ taxstats/article/0,id=173667,00.html. Granted, however, the transfer taxes have never been a major revenue source as compared to other taxes. See Dodge, supra note 2, at 1001-02 ("[T]he revenue-yielding potential of wealth transfer taxes (compared to other taxes) is now considered to be slight, given the political necessity of large exemptions designed to exclude all but the wealthiest taxpayers (transferors or transferees, as the case may be) from the tax." (footnote omitted)).

4. I.R.C. $§ 2056(a)$ (2006); Economic Recovery Tax Act of 1981, Pub. L. No. 97-34 $\S 403(\mathrm{a})(1), 95$ Stat. 172, 301 (codified as amended at I.R.C. $\$ 2056$ (2006)) (repealing I.R.C. $\$ 2056$ (c) (1954), a subsection containing the percentage and dollar limitations of the then-current marital deduction).

5. Table 1-Estate Tax Returns Filed in 2009[1], by Tax Status and Size of Gross Estate, IRS.GOV, http://www.irs.gov/taxstats/indtaxstats/article/0,,id=210646,00.html (last visited July 5, 2011) [hereinafter Table 1] (follow "2009" hyperlink). The next largest deduction is the charitable deduction. See Estate Tax Statistics, IRS.GOV, 
uninformed, only at the couple's last surviving spouse's death. Regarding the estate tax returns filed in 2009, "97 percent of the estates of married decedents, and 43 percent of estates overall, reported deductions for marital bequests, for a total of $\$ 62$ billion. Only 10 percent of estates with a marital bequest owed estate tax." That means that there has been and likely will continue to be what is not an insignificant loss of current revenue because of this deduction. ${ }^{7}$

The benefit of the marital deduction is deferral. ${ }^{8}$ It is true that many scholars see deferral by means of the marital deduction as not producing an economic advantage, ${ }^{9}$ but merely a

http://www.irs.gov/pub/irs-soi/10esesttaxsnap.pdf (last visited Aug. 26, 2011) ("About 19 percent of estates claimed a charitable bequest deduction, for a total of $\$ 16$ billion. Estates with $\$ 20$ million or more in gross estate accounted for over 58 percent of this total, despite representing only 3 percent of filers.").

6. Estate Tax Statistics, supra note 5.

7. While the current exemption is $\$ 5$ million and the current rate is $35 \%$ (rather than $\$ 3.5$ million and $45 \%$, as in 2009), using the estate tax data from returns filed in 2009 , approximately $\$ 46.3$ billion of the $\$ 62$ billion in bequests going to a surviving spouse were from returns of decedents with gross estates of over $\$ 5$ million; $35 \%$ of the approximately $\$ 46$ billion is more than $\$ 16$ billion. Decedents with a gross estate of $\$ 20$ million or more, by themselves, took marital deductions of approximately $\$ 24$ billion. Table 1, supra note 5 .

8. See Joseph M. Dodge, A Deemed Realization Approach Is Superior to Carryover Basis (and Avoids Most of the Problems of the Estate and Gift Tax), 54 TAX L. REV. 421, $464 \&$ n. 175 (2001) ("The property subject to deferred taxability can shrink or grow in the interim. Thus, the marital-deduction scheme cannot be characterized as a pure tax deferral mechanism. True tax deferral would entail determining the incremental tax due on the first spouse's marital transfers (in the absence of a marital deduction) and postponing payment of the incremental tax with an appropriate interest charge.").

9. While calculations on present value and future value show that there is no economic benefit to deferral within the context of time value of money, because there are many variables (change of rates, exemption amounts, estate tax repeal, plus personal and family life changes), few see the disadvantages of deferral. Moreover, because the gift and estate taxes are currently reunified and those transfer taxes are imposed at a flat rate, there is no current argument for the alternative of estate equalization between the spouses in order to use up both spouses' lower tax brackets. Other advantages proffered are: having more funds available for the surviving spouse herself, for her to make tax-free gifts, or postponing liquidity issues. See, e.g., Jeffrey N. Pennell, Estate Tax Marital Deduction, 843-2d Tax Mgmt. (BNA), at A-16 (2004) (noting that in certain circumstances, the marital deduction may result in greater taxes than if no deduction was taken). Likewise, Professors Dodge and Crawford, and I have stated:

The value of deferral is a function of mainly of the period of survival by the surviving spouse, but also the nature of the assets involved (potential for appreciation, depreciation, and income yield) and their allocation between marital and by-pass transfers and predictions about the likelihood that the surviving spouse will consume (or give away) whatever is available to her. Under an assumption of survival for at least a modest period (three years) the conventional estate planning wisdom since the unlimited marital deduction was instituted in 1981 was to prefer the tax-deferral plan to the estate-splitting plan, as a general matter. Texts, manuals, and formbooks have steered estate practitioners in that direction. 
psychological one. ${ }^{10}$ However, even if the two choices (paying the tax now on the present value versus paying a larger tax on the appreciated property later) are the same financially, ${ }^{11}$ with the large deficit, ${ }^{12}$ the government needs more money now. ${ }^{13}$ Moreover, with the current flat estate tax rate, there is no economic incentive to pay some tax at the decedent's death in order for each spouse to take advantage of his or her own lower marginal rate brackets. ${ }^{14}$ With one estate tax rate, there are no other brackets.

Indeed, it makes much sense in this era of "no tax increases"15 $^{15}$ at least to reform current deferral sections, ${ }^{16}$ especially where there is no coherent policy rationale to foster deferral in the first instance. The QTIP $^{17}$ provisions were enacted

Joseph M. Dodge, Wendy C. Gerzog \& Bridget J. Crawford, Federal TaXes on GRATUITOUS TRANSFERS: LAW AND PLANNING 292 (2011).

10. See Pennell, supra note 9, at A-15 (reasoning that individuals would prefer to delay payment of debt).

11. The equivalence of these two values assumes, for example, little consumption between the two spouses' dates of death, a correspondence between the assets' actual growth and their imputed growth expectancy, no changes in estate tax rates or exemptions, and no use of the surviving spouse's exemption amount for any of the first decedent's assets. See Daniel B. Evans, Timing of Transfers: The Fallacy of Future Value Analysis, ProB. \& ProP., Jan.-Feb. 1993, at 23, 24-25 (using an example to show that there is no economic difference between paying taxes immediately and deferring until the spouse's death).

12. The national deficit is over $\$ 14$ trillion. See U.S. National Debt Clock: Real Time, U.S. DEBT ClOCK.ORG, http://www.usdebtclock.org (last visited Aug. 26, 2011) (providing a real-time calculation of U.S. debt).

13. Id.; see Steve R. Johnson, Fog, Fairness, and the Federal Fisc: Tenancy-bythe-Entireties Interests and the Federal Tax Lien, 60 Mo. L. REv. 839, $846-47$ (1995) (explaining why the government needs tax revenue).

14. See DODGE, GERZOG \& CRAWFORD, supra note 9, at 292 (reasoning that with the new flat-rate estate tax, there is no advantage to 50-50 estate splitting). Since 2007, the transfer tax rate has been a flat rate with no other brackets; all taxable estates have only one rate regardless of their size. Between 2007 and 2009, that rate was 45\%; from 2010 to 2012 , the rate is $35 \%$. Id.

15. See, e.g., Robert Parry, Budget Crisis? Duh, Tax the Rich!, CONSORTIUMNEws.com (Feb. 24, 2011), http://www.consortiumnews.com/2011/022411.html (arguing that higher taxes on the wealthy, although justifiable, have not been enacted because of strong political opinions against tax increases).

16. This Article is intended only to review the question of deferral in the context of the marital deduction; however, there are other deferral provisions that might well be reconsidered in light of our current budget needs and our resistance to tax increases.

17. QTIP is the acronym for "qualified terminable interest property" and is defined as property: "(I) which passes from the decedent, (II) in which the surviving spouse has a qualifying income interest for life, and (III) to which an election under this paragraph applies." I.R.C. §2056(b)(7)(B)(i) (2006); see also I.R.C. \$2523(f)(2) (2006) (defining "qualified terminable interest property" in the context of gifts to spouses); Treas. Reg. $\S \S 20.2056(\mathrm{~b})-7$ (b) (as amended in 2004), 25.2523(f)-1(b) (2004) (defining "qualified terminable interest property"). This form of the marital deduction was enacted in 1981. See Economic Recovery Tax Act of 1981, Pub. L. No. 97-34, § 403(a)(1), 95 Stat. 172, 301 
to check the appeal of the unlimited marital deduction to forestall husbands from passing too much property to their widows by the lure (financial or otherwise) of deferral. ${ }^{18}$

The purpose of this Article is two-fold: (1) to attack the QTIP marital deduction, which has by far become the most popular form of the marital deduction; ${ }^{19}$ and (2) to promote the invigoration of the $\mathrm{PAT}^{20}$ mode of the marital deduction. Because

(codified as amended at I.R.C. § 2056 (2006)) (repealing I.R.C. §2056(c) (1954) (containing the percentage and dollar limitations of the then-current marital deduction).

18. See Major Estate and Gift Tax Issues, Part 2 of 2: Hearing Before the Subcomm. on Estate and Gift Taxation of the S. Comm. on Fin., 97th Cong. 206 (1981) (statement of John A. Wallace, on behalf of the American College of Probate Counsel on Estate and Gift Tax Reform) ("In many instances a taxpayer will forego the benefit of the marital deduction because of a concern that the surviving spouse will direct the property at his or her death to persons who are unacceptable to the taxpayer."). In fact, the American College of Probate Counsel would only support the unlimited marital deduction if Congress also enacted the QTIP provisions. Id. The American Bankers Association would endorse the unlimited marital deduction only if "a qualitative change is also made so that a current beneficial interest in property would qualify for the deduction." Major Estate and Gift Tax Issues, Part 1 of 2: Hearings Before the Subcomm. on Estate and Gift Taxation of the S. Comm. on Fin., 97th Cong. 158 (1981) (statement of Donald W. Thurmond, on behalf of the American Bankers Association on Estate and Gift Reform).

19. The popularity of the QTIP is clear to practitioners and scholars alike. See, e.g., Nancy G. Fax \& Deborah A. Cohn, Marital Deduction, in USING AND DRAFTING TRUSTS IN ESTATE PlanNing 39, 46 (2009) ("The Clayton QTIP trust has become a more popular planning device since the enactment of the Economic Growth and Tax Relief Reconciliation Act of 2001 (EGTRRA) because of its flexibility and because it permits income tax planning and use of the additional $\$ 3$ million basis adjustment that would then be available to assets that pass to the surviving spouse." (citation omitted)); Jon E. Steffensen, The Married Couple with a Taxable or Potentially Taxable Estate, in DRAFTING ESTATE PlanS ch. 3, \& 3.1.1, at 3-11 (Judith R. Mendel ed., 2d ed. 2010) ("The QTIP trust has become the most popular marital deduction planning device."); Ira Mark Bloom, The Treatment of Trust and Other Partial Interests of the Surviving Spouse Under the Redesigned Elective-Share System: Some Concerns and Suggestions, 55 ALB. L. REv. 941, 955 (1992) ("This scenario addresses both the multiple-marriage society phenomenon and the popularity of QTIP dispositions." (footnote omitted)); Dodge, supra note 8, at 466 ("In estates of the well-off, the most popular form of marital bequest is the QTIP trust....").

20. A PAT is a power of appointment trust that allows the marital deduction for the estate tax under I.R.C. $\S 2056(\mathrm{~b})(5)$ and for the gift tax under $\$ 2523(\mathrm{e})$. The marital deduction for the gift statute requires that the surviving spouse be:

[E]ntitled for life to all the income from the entire interest, or all the income from a specific portion thereof, payable annually or at more frequent intervals, with power in the donee spouse to appoint the entire interest, or such specific portion (exercisable in favor of such donee spouse, or of the estate of such donee spouse, or in favor of either, whether or not in each case the power is exercisable in favor of others), and with no power in any other person to appoint any part of such interest, or such portion, to any person other than the donee spouse.

I.R.C. $\S 2523(\mathrm{e})$ (2006). Moreover, to qualify as a PAT, the surviving spouse's general power of appointment must be "exercisable by such spouse alone and in all events." Id. Because the surviving spouse must hold not only the income interest in the trust, but also a general power of appointment over the corpus of the trust exercisable in favor of her or her estate, the PAT is generally considered to be a quasi-equivalent of ownership. See id. 
deferral due to the marital deduction is only justified when property ownership passes to the surviving spouse and not to a third party beneficiary, the marital deduction should be limited to outright property transfers to the surviving spouse and to PATs or similar formats, which benefit the surviving spouse. ${ }^{21}$

\section{CRITIQUing THE QTIP}

Previously, I have criticized the QTIP on the basis that the QTIP provisions are both illogical and sexist. ${ }^{22}$ I still hold to that view. The QTIP provisions are illogical because they conflict with the stated public policy goal of the marital deduction, which is to tax marital property when it leaves the marital unit and passes to other beneficiaries. ${ }^{23}$ Because the goal of the marital deduction is to tax property when it leaves the marital unit and because the QTIP expressly endorses passing the property to third parties at the first spouse's death, the QTIP undermines the fundamental rationale for the marital deduction. Thus, the QTIP trust property should logically be taxed when the property leaves the marital unit, and that is when the husband, and not the widow, dies.

Likewise, the QTIP provisions are sexist. They treat women as invisible spouses, and they equate giving an income interest to women with giving them the corpus. With the QTIP, the first spouse to die controls the disposition of the corpus, and he selects the decisionmaker who will make the QTIP election. ${ }^{24}$ The QTIP provisions implicitly equate giving an income interest to women

(requiring a power of appointment in the donee spouse); George Craven, Powers of Appointment Act of 1951, 65 HARV. L. REV. 55, 63 (1951).

21. See I.R.C. $\$ 2056(b)(1)$ (2006) (disallowing a deduction when an interest is passed to anyone other than the surviving spouse).

22. See generally Wendy C. Gerzog, The Marital Deduction QTIP Provisions: Illogical and Degrading to Women, 5 UCLA WOMEN'S L.J. 301 (1995); Wendy C. Gerzog, Estate of Clack: Adding Insult to Injury, or More Problems with the QTIP Tax Provisions, 6 S. CAL. REV. L. \& WomEN's STUD. 221 (1996); Wendy C. Gerzog, The Illogical and Sexist QTIP Provisions: I Just Can't Say It Ain't So, 76 N.C. L. REv. 1597 (1998); Wendy C. Gerzog, Solutions to the Sexist QTIP Provisions, 35 REAL PROP. PROB. \& TR. J. 97 (2000).

23. See Lawrence Zelenak, Taking Critical Tax Theory Seriously, 76 N.C. L. REV. 1521, 1544 (1998) (explaining that the marital deduction is based on the idea that a husband and wife are "so much a single unit that it is only fair to disregard transfers between them"). Indeed, that purpose is the rationale of the nondeductible terminable interest rule embedded in the statute. Without the QTIP provisions, this rule would apply to a QTIP transfer, making it ineligible for the marital deduction. Under $\$ 2056(\mathrm{~b})(1)$, if the surviving spouse's property interest terminates and passes to someone other than the surviving spouse, the interest cannot qualify for the marital deduction. I.R.C. $\$ 2056$ (b)(1) (2006).

24. See Joseph M. Dodge, A Feminist Perspective on the QTIP Trust and the Unlimited Marital Deduction, 76 N.C. L. REv. 1729, 1731 (1998) (noting that a widow has no power of disposition or control under a QTIP trust because property passes to the beneficiaries that had been designated by the deceased husband). 
with giving them the property itself because, unlike the other exceptions to the terminable interest rule, in which the widow is given a rough equivalent to outright ownership of the corpus, the QTIP provisions allow a marital deduction for the full value of the property at the husband's death even though the surviving spouse, the other half of the marital unit, receives only the income interest in that property. ${ }^{25}$

I have explained that the original proposals framed all of the examples of QTIP transfers as proceeding from the husband to his wife; that all of the descriptions and discussions in the American Law Institute project as well as in the Treasury recommendations identify the donee spouse as a woman; and that in order to support the QTIP measure, the Treasury Department compiled statistics only on the number of years widows survived their husbands and none on the years widowers survive their wives. ${ }^{26}$ Moreover, statistically, a woman is likely to be the surviving spouse:

The greater probability of female estate tax decedents to report a tax liability, compared to their male counterparts, may be explained by a combination of marital status and age at death. Estates of females are taxable in 58.0 percent of all cases, whereas estates of males are taxable in only 35.0 percent of all cases.... [F]emale decedents are more likely to be widowed; since they live longer than their spouses, while male decedents are more likely to be married and therefore utilize the available marital deduction. For the 2001 population as a whole, females bequeathed only $\$ 13.5$ billion to their spouses, while males bequeathed almost $\$ 58.6$ billion. $^{27}$

In these tough economic times with a huge national deficit, there is a clear, additional financial incentive to deny tax deferral to a QTIP trust: we cannot afford to delay receipt of revenue in this severe financial crisis when the QTIP deferral is not supported by any meaningful policy rationale. ${ }^{28}$ Deferring a couple's payment of their appropriate transfer tax liability should be a benefit restricted to actual intraspousal transfers and should not be available to transfers outside the marital unit, such as those specifically sanctioned by the QTIP provisions. As an

25. See I.R.C. $\$ 2056(\mathrm{a}),(\mathrm{b})(7)(\mathrm{B})(\mathrm{i})-(\mathrm{ii})$ (2006) (providing that a QTIP that provides an income interest from trust property for life qualifies for the marital estate tax deduction).

26. See Gerzog, The Marital Deduction QTIP Provisions, supra note 22, at 320-25.

27. Eller, supra note 1, at 4-5.

28. See I.R.C. § 2056(b)(1) (2006) (stating that no deduction should be allowed if the interest passes to someone other than the surviving spouse). 
appropriate alternative, the PAT is a trust device that ensures that the marital deduction embodies an intraspousal transfer. ${ }^{29}$

Unfortunately, however, besides conferring deferral for nonmarital transfers, the QTIP offers the flexibility of postmortem planning and other attractive features. Thus, even when a couple is married only once (and to each other), their estate planner typically advises them not to leave property to each other, either outright or in trust, but instead to create a QTIP. $^{30}$

In a first marriage, unity of interest demands that the survivor transmit the family wealth to the children of the marriage, without the need for any restrictive planning structure. ...

... [J] ustifications for denial to a surviving spouse of autonomy over property rest on an extremely weak, but traditionally condoned, foundation. Estate planning lawyers too long have failed to question the soundness of that foundation in plying their trade. ${ }^{31}$

Because it is the flexibility of the QTIP that makes it so popular (apart from its dead-hand control), ${ }^{32}$ to "dress up" the PAT to make it as appealing as the QTIP, the PAT provisions need to be amended to make a PAT more multifunctional. Essentially, the PAT needs to be supercharged.

\section{DEFERRAL IN THE CONTEXT OF THE MARITAL DEDUCTION}

An economic analysis of deferral in the context of the marital deduction indicates that there is no, or at any rate only an inconclusive and an indeterminable, financial benefit to deferring the payment of estate taxes. ${ }^{33}$ To the extent that present value estimates are accurate, there is no difference to paying a tax now or deferring the tax until the second spouse's death when it will

29. I.R.C. § 2523(e) (2006).

30. Henry M. Ordower, Trusting Our Partners: An Essay on Resetting the Estate Planning Defaults for an Adult World, 31 REAL PROP. PrOB. \& TR. J. 313, 315-16 (1996) ("In particular, estate planning lawyers need to revise their current tendency to encourage their primary client-generally the husband-to accept autonomy-denying default settings that discount the independent decisionmaking abilities of the client's spouse and children. These default settings, especially holding gifts in trust, rather than effecting them outright, and the selection of trustees other than the spouse for gifts in trust degrade the spouse by influencing the client to disempower the spouse following the client's death." (footnotes omitted)).

31. Id. at $340,344$.

32. See infra Part V (discussing the advantages of the QTIP trust).

33. Pennell, supra note 9, at A-15. 
apply to the appreciated assets in the QTIP trust. ${ }^{34}$ However, as many have pointed out, ${ }^{35}$ there are unknown variables that make that economic truism, while generally accurate, in specific situations not necessarily so. ${ }^{36}$

That said, there is a financial incentive to use a QTIP in circumstances where a moneyed spouse dies first and the surviving spouse owns little or no property of her own. The moneyed spouse is able to transfer more property tax-free to third parties because he is effectively able to double his exemption amount. By means of the QTIP, for the relatively small cost of giving his spouse an income interest in the QTIP trust (which interest amounts to a pittance in relation to the value of the remainder interest because of the requirements of trust income $)^{37}$ the decedent may, without his spouse's permission, use his surviving spouse's exemption amount in addition to his own exemption. ${ }^{38}$ Although there is a right of recovery for the surviving spouse's estate to recoup any tax incurred by reason of inclusion of the QTIP trust in her estate, when there is no estate tax due, there is no right of recovery. ${ }^{39}$ Thus, if the decedent has $\$ 10$ million in his estate and the surviving spouse has no assets, he may, without her agreement to do so, employ a QTIP trust to transfer the $\$ 10$ million to his children from a former marriage tax-free. Further, when the

34. DODGE, GERZOG \& CRAWFORD, supra note 9, at 292.

35. See supra note 9.

36. See supra note 11 and accompanying text (identifying necessary assumptions leading to the conclusion that there is no financial difference between paying tax immediately and deferring payment).

37. See Dodge, supra note 24 , at $1741-42$ (explaining how, at a $4 \%$ discount rate, the QTIP beneficiary's ten year income interest is worth only $30 \%$ of the trust corpus). Moreover, where the adult child from a former marriage is the executor, there is a clear self-interest in choosing QTIP treatment. Estate planners advise that the trust appoint an independent executor to make that decision. See infra Part XI.

38. See Dodge, supra note 24, at 1738-40 (explaining how a husband could reduce his taxable estate to the amount that will produce a zero tax after subtracting the qualified marital deduction under the unified transfer tax credit).

39. See I.R.C. $\$ 2207 \mathrm{~A}(\mathrm{a})(1)$ (2006) (providing the surviving spouse's estate with a right to recovery when the inclusion of the QTIP trust in her estate under I.R.C. $\$ 2044$ produces a tax). In the example in the text, there is no tax produced by such inclusion and thus that statute does not benefit her. I.R.C. $\$ 2207 \mathrm{~A}(\mathrm{a})(1)$ provides:

If any part of the gross estate consists of property the value of which is includible in the gross estate by reason of section 2044 (relating to certain property for which marital deduction was previously allowed), the decedent's estate shall be entitled to recover from the person receiving the property the amount by which-(A) the total tax under this chapter which has been paid, exceeds (B) the total tax under this chapter which would have been payable if the value of such property had not been included in the gross estate.

I.R.C. $\$ 2207 \mathrm{~A}(\mathrm{a})(1)(2006)$. 
QTIP trust exceeds double the exemption amount, the statutory recovery relief is limited to the amount of estate tax liability caused by inclusion of the QTIP trust; that figure does not take into account that the third party beneficiaries of the QTIP trust gain to the extent (up to another $\$ 5$ million) that transfers to those third parties utilize the surviving spouse's exemption amount. ${ }^{40}$ And, she has no say in the matter if she has not been appointed the executor of the decedent's estate since it is the executor who makes the QTIP election. ${ }^{41}$ Finally, bypassing his widow's input, if the decedent appoints an adult child from the decedent's earlier marriage to be the executor, that child will have a real economic interest to elect QTIP treatment. ${ }^{42}$ That is, if he is also the remainder beneficiary of the QTIP trust, he will save $\$ 1.75$ million by doing so. ${ }^{43}$ Deferral in that case means an actual economic advantage to decedent's transfers to third parties outside the marital unit.

Consistent with the modern rationale behind the marital deduction, which is that transfers between spouses are transfers within the marital unit because the marital unit functions as one ${ }^{44}$ the marital deduction should apply only for transfers

40. This treatment contrasts with the newly enacted portability provision wherein the executor of the decedent's estate must make an election in order to permit the surviving spouse to use the decedent's unused exemption. See infra Part VII. In addition, although I.R.C. $\$ 2207 \mathrm{~A}$ provides a right of recovery for any additional taxes incurred by the surviving spouse because of inclusion of the QTIP trust in her estate, he may waive that recovery right. I.R.C. $\S 2207 \mathrm{~A}(\mathrm{a})(2)$ (2006) ("Paragraph (1) shall not apply with respect to any property to the extent that the decedent in his will (or a revocable trust) specifically indicates an intent to waive any right of recovery under this subchapter with respect to such property."). When the couple obtains estate planning advice as a couple, which is traditionally in fact how the couple is represented, it is more probable that documents will be drafted with such a waiver. See, e.g., Eisenbach v. Schneider, 166 P.3d 858, 864 (Wash. Ct. App. 2007) (imposing a requirement of an express waiver of the right to recovery with respect to a QTIP trust in the decedent spouse's will by reference to I.R.C. $\$ 2207 \mathrm{~A}$ ); infra note 44 (suggesting that most couples view their property as "ours," not "his" or "hers").

41. I.R.C. $\S 2056(\mathrm{~b})(7)(\mathrm{B})(\mathrm{v})(2006)$.

42. See infra Part XI (discussing the inherent conflict of interest between the surviving spouse and the children from decedent's earlier marriages in a QTIP trust).

43. That is, the surviving spouse's $\$ 5$ million multiplied by $35 \%$, which is the current estate tax exemption multiplied by the current flat estate tax rate. Tax Relief, Unemployment Insurance Reauthorization, and Job Creation Act of 2010, Pub. L. No. 111-312, § 302, 124 Stat. 3296, 3301 (to be codified at I.R.C. $\S 2010$ (2006)).

44. See, e.g., Treasury Department's General and TeChNiCal Explanation of H.R. 3849: ADMINISTRATION'S ECONOMIC RECOVERY TAX ACT OF 1981, 97TH CONGRESS, 1St SEsS (JUNe 23, 1981) 39 (1981), reprinted in TAX MANagement Primary Sources, SERIES IV (BNA) 8 (1982) (noting that a husband and wife are essentially treated as a single economic unit for transfer tax purposes); Federal Estate and Gift Taxes: Public Hearings and Panel Discussions Before the H. Comm. on Ways and Means on the General Subject of Federal Estate and Gift Taxes, Part 2 of 2, 94th Cong. 1187 (1976) (statement of Charles M. Walker, Assistant Secretary for Tax Policy, Department of the Treasury) 
wholly between the two spouses and not to transfers to third parties. Where the surviving spouse has little or no assets of her own, the federal fisc would not only receive its money now when it has an acute need but our government would also receive more of that revenue.

\section{THE QTIP TRUST: MINIMAL SPOUSAL OWNERSHIP}

The QTIP does not provide the surviving spouse with significant ownership rights. The widow receives a relatively small annual income from the trust, ${ }^{45}$ which may be further reduced by the decedent's appointing an unfriendly trustee to manage the trust. ${ }^{46}$ As Professor Dodge explained:

First, the concept of "income" under the law of trusts is narrower than economic income: capital gains and appreciation are excluded. Second, the trustee's normal duty is to preserve the corpus against erosion by inflation and to balance fairly the interests of the income beneficiary and the remainder. These conditions produce a situation in which a substantial portion of the economic return is (or can be) devoted to the remainder interest. Third, trustees are subject to the prudent investor rule constraining investments. Fourth, the "income" is net of trustee fees charged against income, an expense that would be eliminated if the widow owned the property outright. ${ }^{47}$

(stating that property is often transferred from separate ownership to joint or community ownership because many families regard their property as being generated by the combined efforts of husband and wife); U.S. TREASURY DEP'T, TAX REFORM STUDIES AND Proposals (Comm. Print 1969), reprinted in H. CoMm. on WaYs \& MEANS, 94TH ConG., Background Materials on Federal Estate and Gift Taxation 258 (Comm. Print 1976) (noting that the then-current system of taxing transfers between spouses did not accord with the understanding that property accumulated by the husband and wife is owned by both); AM. LAW INST., FEDERAL ESTATE AND GIFT TAXATION (1969), reprinted in H. COMM. ON WAYS \& MEANS, 94TH CONG., BaCKGROUND Materials ON FEDERAL Estate AND GIFT TAXATION 355 (Comm. Print 1976) ("[T]he often expressed attitude of husband and wife [is] that the property is "ours" without regard to the technical legal ownership requirements.").

45. See Dodge, supra note 24 , at 1741-42 (listing the conditions that produce a situation in which a substantial portion of the economic return from the QTIP trust is devoted to the remainder interest and the surviving spouse receives only a small amount of the asset value); Dodge, supra note 8, at 466 ("Exemption from capital gains tax mostly benefits the nonspousal remainders of QTIP trusts, since gains and losses from trust asset transactions inure to corpus, not income.").

46. Often, QTIP trusts are created for a decedent who has married more than once and has children from those previous marriages. See George M. Schain, Marital Trust v. QTIP: Advice for Estate Planners, 49 Mo. L. REv. 741, 761-62 (explaining that the QTIP may be most attractive to persons who have remarried). Appointing as trustee or executor an adult child or anyone closely related to that child often creates a conflict of interest. See infra Part XI.

47. Dodge, supra note 24 , at 1741-42 (footnotes omitted). A decedent can, however, express his explicit intent that the trust is to primarily benefit the surviving spouse. 
Indeed, the QTIP trust is promoted by estate planners for these minimal spousal ownership qualities. ${ }^{48}$

The other, and perhaps more compelling reason [to establish a QTIP trust], is that you may want to take advantage of the marital deduction for transfers made to your spouse in trust yet want to limit the power or ownership rights he or she has over the trust assets. The restrictive ownership provisions of a QTIP trust are particularly useful for second marriages since you may want to ensure that the amounts held in the trust will ultimately pass to your children or family and not the children or family of your second spouse. ${ }^{49}$

The Tax Court has acknowledged that the surviving spouse does not in fact own the property in the QTIP trust, but is merely treated by statute as owning the corpus in the trust. ${ }^{50}$ In Mellinger, the decedent owned stock in three different ways: some of the shares she owned outright, some in a revocable trust, and some in a QTIP trust established by her predeceased husband. Although the QTIP trust was included and taxed in her estate, ${ }^{51}$ the court considered the issue of whether to aggregate the shares in her QTIP trust with similar shares she owned outright or in her revocable trust in order to value those securities and apply either a minority discount or a control premium. The government argued that decedent was the owner for purposes of valuation as well as for purposes of inclusion. However, the court held that both the statute and its legislative history were silent on this issue. Stating that "at no time did [the surviving spouse] possess, control, or have any power of

Benjamin H. Pruett, Tales from the Dark Side: Drafting Issues from the Fiduciary's Perspective, 35 AM. C. TR. \& EST. CouNS. J. 331, 342 (2010). Some have suggested increasing the surviving spouse's interest, particularly in times of low interest rates, by adopting a total return unitrust income interest, with the option of petitioning the court for a conversion to an income-based interest during higher interest rate periods where the decedent has stated his intent to benefit the surviving spouse. Louis S. Harrison, Erica E. Lord \& Kirk W. Dillard, Total Return Trusts Give Trustees Flexibility in Ever-Changing Markets, 91 ILL. B.J. 240, 242-44 (2003).

48. See, e.g., The Benefits of a QTIP Trust, SIGMA Nu EDUc. Found., http://www.sigmanufoundation.org/snef-giving/gift-planning/estate-planning/qtip-trust (last visited Aug. 28, 2011) ("The QTIP trust, however, ensures that your wishes are carried out. It qualifies for the marital deduction without ever giving your spouse control over principal.").

49. The Benefits of QTIP Trusts, WILMINGTON TRUST, http:/www.wilmingtontrust.com/ wtcom/index.jsp?fileid=3000306 (last updated June 1, 2010).

50. See Estate of Mellinger v. Comm'r, 112 T.C. 26, 36 (1999) (explaining that the surviving spouse should not be treated as the owner of the QTIP property for purposes of aggregation), acq., 1999-52 C.B. 763 (1999).

51. Id. at 32; see I.R.C. $\S 2044$ (2006) (providing for inclusion of QTIP property in the gross estate of the surviving spouse). 
disposition over the FOH shares in the QTIP trust," the court refused to aggregate the shares in the QTIP estate with the other shares she actually owned and allowed the widow a minority discount. $^{52}$

Likewise, in Bonner, where the surviving spouse died owning fractional interests in real property both outright and in a QTIP trust, the Fifth Circuit refused to aggregate those interests as the statute did not require such merger and the surviving spouse never controlled the property. ${ }^{53}$ Allowing a twenty-five percent discount, the court stated that "[t]he assets in the QTIP trust could have been left to any recipient of [the decedent's] choosing, and neither [the surviving spouse] nor the estate had any control over their ultimate disposition..$^{34}$ Moreover, the circuit court explained that public policy favored the taxpayer's position.

The estate of each decedent should be required to pay taxes on those assets whose disposition that decedent directs and controls, in spite of the labyrinth of federal tax fictions. In this case, [the decedent] controlled the disposition of [the] assets, first into a trust with a life interest for [the surviving spouse] and later to the objects of [the decedent's] largesse. The assets, although taxed as if they passed through [the surviving spouse's] estate, in fact were controlled at every step by [the decedent], which a tax valuation with a fractional interest discount would reflect. At the time of [the surviving spouse's] death, [the] estate did not have control over [the decedent's] interests in the assets such that it could act as a hypothetical seller negotiating with willing buyers free of the handicaps associated with fractional undivided interests. The valuation of the assets should reflect that reality. ${ }^{55}$

With such a minimal spousal ownership interest in the QTIP trust, with the decedent's owning the QTIP property and passing the QTIP property to third parties at his death, and with the country's large deficits, such property should be taxed at the decedent's death. ${ }^{56}$ Such a transfer should not receive a deferral

52. Mellinger, 112 T.C. at 36.

53. Estate of Bonner v. United States, 84 F.3d 196, 197-98 (5th Cir. 1996).

54. Id. at 198.

55. Id. at 199 (emphasis added). Why the court maintained that valuation should reflect reality when a major purpose of the statute is not to reflect reality is unclear. Indeed, the lack of logic in the statute is another reason that the QTIP provision should be repealed. See supra notes $22-23$ and accompanying text (arguing that the QTIP provisions undermine the public policy goal of the marital deduction).

56. By creating a QTIP and naming third parties as remainder beneficiaries, it is the decedent who has transferred the QTIP property outside the marital unit. Indeed, the 
benefit of the marital deductions; that deferral is just too costly and unjustified.

\section{THE FLEXIBILITY OF THE QTIP TRUST}

Everyone loves the QTIP because of its flexibility; indeed, it is difficult to ignore or reject the very useful options available to the QTIP trust. Those advantages include a partial QTIP election, ${ }^{57}$ a reverse QTIP election, ${ }^{58}$ a state-only QTIP election, ${ }^{59}$ a Clayton contingent income interest election (applying the relation back doctrine) ${ }^{60}$ and a marital-charitable trust. ${ }^{61}$ Many of these benefits are devices that involve postmortem estate planning. ${ }^{62}$ Postmortem estate planning allows decisions to be made based on facts actually known at the first spouse's death.

\section{A. A Partial QTIP Election}

Under the QTIP provisions, the executor may elect to have a specific portion of a trust qualify as a QTIP trust with respect to which portion of the decedent's estate receives a marital deduction. ${ }^{63}$ The election of a partial interest in a trust for QTIP treatment must be expressed as either a fraction or percentage share of the trust. ${ }^{64}$ After the first spouse dies, the executor can review the value of the assets in the decedent's estate and determine the amount of assets eligible for the QTIP marital deduction that are necessary to avoid current estate tax liability and then make a QTIP election with respect to that portion only. ${ }^{65}$ If, or to the extent that, the exemption amount

QTIP trust is the quintessential nondeductible terminable interest. See I.R.C. $\$ 2056(b)(1)$ (2006) (disallowing deduction with respect to QTIP property if an interest in such property passes from decedent to any person other than surviving spouse).

57. See infra Part V.A.

58. See infra Part V.B.

59. See infra Part V.C.

60. See infra Part V.D.

61. See infra Part V.E.

62. See, e.g., Harold WeInStock \& MARTin A. NeUmann, Planning AN Estate: A GUIDEBOOK OF PRINCIPLES AND TECHNIQUES 76-77 (4th ed. 2002) (discussing QTIP trust as a postmortem planning device); Irene A. Vlissides, Estate of Clack v. Comm'r: An End to the Conflict Over Contingent QTIP Elections, 6 GEO. MASON L. REV. 163, 170-71, 182 (1998) (discussing the postmortem flexibility provided by a partial QTIP election).

63. I.R.C. $\S 2056(\mathrm{~b})(7)(B)(i v)(2006)$; Treas. Reg. $\S 20.2056(\mathrm{~b})-7(\mathrm{~b})(1)(\mathrm{ii}),-7(\mathrm{~b})(2)(\mathrm{ii}),-7(\mathrm{~h})$ (as amended in 2004).

64. I.R.C. $\S 2056(b)(10)(2006)$; Treas. Reg. $\$ 20.2056(b)-5(c)$ (as amended in 2004).

65. I.R.C. $\$ 2056(\mathrm{~b})(7)(\mathrm{B})(\mathrm{v})(2006)$ (allowing the executor to make elections with respect to the estate of the surviving spouse). 


\section{shelters the trust from taxation, no QTIP election is necessary. ${ }^{66}$}

A PAT qualifies for the marital deduction, and currently no election can change that status. Portability for estate tax purposes allows a couple to employ a PAT for all of decedent's assets while preserving the couple's aggregate estate tax exemption. ${ }^{67}$ This Article proposes that the PAT provisions be amended to allow the surviving spouse to elect for a portion of the PAT not to qualify as marital deduction property and to create a taxable estate. That change would allow a part of the assets in a PAT to fund a by-pass trust without first requiring the executor to make a partial disclaimer of that fractional or percentile amount. ${ }^{68}$ The surviving spouse's consent to this election would enable the executor simply to check a box on the estate tax return indicating what fractional part or percentage amount would be taxed in the decedent's estate. Such elections are typical of much tax treatment today where the taxpayer foregoes beneficial tax treatment, ${ }^{69}$ such as deferral of

66. I.R.C. $\S 2056(\mathrm{~b})(7)(\mathrm{B})-(\mathrm{C})(2006)$. Where a QTIP election proves unnecessary to avert estate taxes after the executor has made the election, Rev. Proc. 2001-38, explains how to nullify that election. Rev. Proc. 2001-38, 2001-1 C.B. 1335-36. This procedure is used when the taxable estate is itself below the applicable exclusion amount or when the estate needlessly elected QTIP treatment for a credit shelter trust. The revenue procedure also indicates when relief is unavailable (e.g., a reduce-to-zero formula election or a protective election under Treas. Reg. $\$ 20.2056(\mathrm{~b})-7(\mathrm{c}))$. Id. at 1335. See, e.g., I.R.S. Priv. Ltr. Rul. 02-26-020 (June 28, 2002), available at http://www.irs.gov/pub/irs-wd/ 0226020.pdf (stating that an election to treat property as QTIP is not necessary to reduce the estate tax to zero when no tax would be imposed whether or not the election was made); I.R.S. Priv. Ltr. Rul. 02-19-003 (May 10, 2002), available at http://www.irs.gov/pub/irs-wd/0219003.pdf ("The revenue procedure does not apply in situations where a partial QTIP election was required with respect to a trust to reduce the estate tax liability and the executor made the election with respect to more trust property than was necessary to reduce the estate tax liability to zero.").

67. See infra Part VII.

68. She may wish to create a taxable estate for many reasons. For example, she may want to create a by-pass trust, to equalize the couple's estates where there is more than one transfer tax bracket, or to use the credit for tax on prior transfers if she dies shortly after the decedent. See I.R.C. § 2013(c)(2) (2006) (providing for computation of credit by aggregating the property received from two or more transferors). The surviving spouse would create a by-pass trust to use the decedent's exemption and to freeze the value of that bypass trust to enable any post-decedent's-death appreciation in that trust to avoid estate tax when she later dies. I.R.C. $\$ 2013$ (d) (2006) ("The value of property transferred to the decedent shall be the value used for the purpose of determining the Federal estate tax liability of the estate of the transferor...."). Alternatively, I.R.C. Sections 2518 and 2046 allow the spouse to disclaim all or part of her interest in a PAT, just as those provisions allow her to disclaim her income interest in a QTIP trust. I.R.C. $\S \S 2046,2518$ (2006). The benefits of allowing a partial election of the marital deduction as compared to making a partial disclaimer of her interest in a PAT are discussed infra, Part VIII.

69. See, e.g., I.R.C. $\S \S 83(\mathrm{~b}), 2701(\mathrm{c})(3)(\mathrm{C})$ (2006) (providing for elections in the context of performance of services and corporations, respectively). For example, Section 
taxation. ${ }^{70}$ An option for a partial marital deduction election should be extended to PATs to make them more attractive marital deduction vehicles and to allow the PAT to replace the QTIP for flexibility purposes.

\section{B. A Reverse QTIP Election}

The GST provisions allow the executor of the first spouse-decedent's estate to make a reverse QTIP election ${ }^{71}$ in order to preserve any remaining GST exemption amount that the decedent might have, especially where that amount exceeds the amount remaining of his estate tax exemption. ${ }^{72}$ To the extent that the executor makes a reverse QTIP election on the decedent's estate tax return, the decedent, and not the surviving spouse, will be deemed the transferor of that separate QTIP trust for GST purposes. In that way, the couple will be able to benefit fully from each spouse's individual GST exemption. ${ }^{73}$ While less often applied today where the maximum estate tax and GST tax exemptions are identical, ${ }^{74}$ reverse QTIP elections

2701 provides for "qualified payment elections," whereby a transferor with a qualified payment right may elect for that right to be classified as not a qualified payment right and that election may be a partial one. See Treas. Reg. § 25.2701-2(c)(1) (1992) (providing for an election not to treat a qualified payment right as such); infra Part IX (discussing the increased flexibility for couples making estate planning decisions since the $1980 \mathrm{~s}$ ).

70. See Treas. Reg. $\S 25.2701-4(d)(1)$ (1992) (providing an interest holder the option of treating as a taxable event the payment of an unpaid qualified payment occurring more than four years after its due date).

71. I.R.C. § 2652(a)(3) provides:

In the case of $-(A)$ any trust with respect to which a deduction is allowed to the decedent under section 2056 by reason of subsection (b)(7) thereof, and (B) any trust with respect to which a deduction to the donor spouse is allowed under section 2523 by reason of subsection ( $f$ ) thereof, the estate of the decedent or the donor spouse, as the case may be, may elect to treat all of the property in such trust for purposes of [the GST tax] as if the election to be treated as qualified terminable interest property had not been made.

I.R.C. $\S 2652$ (a)(3) (2006).

72. See I.R.C. $\$ 2632(\mathrm{~b})-(\mathrm{c})(2)$ (2006) (setting out rules for the allocation of GST exemption, including any unused portion of the exemption).

73. I.R.C. § 2631(a), (c) (2006).

74. Since 2004, the estate tax and GST tax exempt the same amounts. That is, in 2004 and 2005, both taxes exempted $\$ 1.5$ million; in 2006 to 2008 , $\$ 2$ million; in 2009, $\$ 3.5$ million; in 2010 through 2011, $\$ 5$ million; in 2012, $\$ 5$ million, indexed for inflation. See Darien V. Jacobson, Brian G. Raub \& Barry W. Johnson, The Estate Tax: Ninety Years and Counting, STAT. INCOME BULL., Summer 2007, at 118, 122, 124, available at http://www.irs.gov/pub/irs-soi/ninetyestate.pdf (listing exemption amounts for 2004 through 2009); Tax Relief, Unemployment Insurance Reauthorization, and Job Creation Act of 2010, Pub. L. No. 111-312, §§ 302(a)(1), 303(a), 124 Stat. 3296, 3301 (to be codified at I.R.C. $\S 2010$ (2006)) (modifying the GST and estate taxes starting in 2010). Before 2004, however, the estate tax exemption was less than the GST tax exemption so that from 1986 through 1998 the GST tax exemption was $\$ 1$ million while the estate tax 
are still useful where the decedent has made some lifetime transfers to nonskip persons, ${ }^{75}$ like to his siblings or his children. That is, if the decedent had made gifts, only some of which involved the GST tax in addition to the gift tax, he would have more GST exemption amounts available to use at his death. ${ }^{76}$ For example, if decedent made two gifts during his life, $\$ 1$ million to his grandchild and $\$ 3$ million to his daughter, he would have $\$ 4$ million of his GST tax credit available at his death but only $\$ 1$ million of his estate tax credit unused at that time. ${ }^{77}$

Currently, if the decedent passes all of his assets to his surviving spouse, portability will preserve the deceased spouse's unused estate tax credit. If portability were extended to the GST tax (portability currently only applies to the estate tax), ${ }^{78}$ there would be no need for a reverse QTIP election. Absent that legislative extension, however, the GST provisions should be amended to allow for the severance of a PAT and for a reverse PAT election to be available to the surviving spouse like the law currently does for a QTIP. With that GST tax amendment, the PAT trust for which a reverse PAT election is made would designate the decedent-spouse as the transferor of assets from that trust for GST tax purposes only. Through that change, the couple would be able to use both spouses' full exemption

exemption ranged from $\$ 500,000$ to $\$ 625,000$ in those years. See I.R.C. $\$ 2631$ (a) (Supp. IV 1987) (stating that the GST exemption is $\$ 1$ million); I.R.C. $\$ 2631$ (a) (1988) (stating that the GST exemption is $\$ 1$ million); I.R.C. $\$ 2631$ (1994 \& Supp. IV 1999) (stating that the GST exemption is $\$ 1$ million, and that it is adjusted for inflation beginning in 1998); Jacobson, Raub \& Johnson, supra, at 122 (listing estate tax exemptions for years 1986 through 1998). For 1999 through 2003, the GST exemption was \$1 million, but was adjusted for inflation $(\$ 1,010,000(1999) ; \$ 1,030,000$ (2000); $\$ 1,060,000$ (2001); $\$ 1,100,000$ (2002); \$1,120,000 (2003)). Rev. Proc. 98-61, 1998-2 C.B. 816 (for 1999); Rev. Proc. 99-42, 1999-2 C.B. 572 (for 2000); Rev. Proc. 2001-13, 2001-1 C.B. 341 (for 2001); Rev. Proc. 2001-59, 2001-2 C.B. 627 (for 2002); Rev. Proc. 2002-70, 2002-2 C.B. 850 (for 2003). By contrast, the estate tax exemption was $\$ 1$ million or less in those years $(\$ 650,000$ (1999); $\$ 675,000(2000-2001) ; \$ 1$ million (2002-2003)). Jacobson, Raub \& Johnson, supra, at 122; see also I.R.C. § 2632(b)-(c) (2006) (providing for rules for allocation of GST exemption); Economic Growth and Tax Relief Reconciliation Act of 2001, Pub. L. No. 107-16, § 521(a), 115 Stat. 38, 71 (2001) (codified as amended at I.R.C. $\$ 2010$ (2006)) (changing the applicable GST exemption for years 2002-2009).

75. See I.R.C. § 2613 (2006) (defining skip person and nonskip person).

76. See I.R.C. $\S 2632$ (c) (2006) (providing for allocation of any unused GST exemption when an individual makes lifetime transfers to nonskip persons).

77. The two gifts, a total of $\$ 4$ million, use $\$ 4$ million of the $\$ 5$ million unified credit (the aggregate credit applied to inter vivos (gifts) and testamentary transfers (bequests or devises)), but only $\$ 1$ million of the $\$ 5$ million GST tax exemption.

78. See I.R.C. $\$ 2632(e)(1)$ (2006) (allocating any unused portions of an individual's GST exemption to either property which is the subject of a direct skip occurring upon the individual's death or trusts to which the individual is the transferor). 
amounts for GST tax purposes in the same way that the reverse QTIP provision currently affords such a benefit.

\section{A State-Only QTIP Election}

With the repeal of the state death tax credit, ${ }^{79}$ some states "de-coupled" and enacted their own state estate tax with exemption amounts less than the federal exemption. ${ }^{81}$ To cover the gap between the state and federal estate tax exemption amounts, some states have enacted a state-only QTIP election, which to some degree parallels the reverse QTIP election. ${ }^{82}$ In a separate trust that does not qualify for the federal marital deduction because no QTIP election is made, the executor is allowed to make a state-only QTIP election for the gap amount solely for state estate tax purposes. ${ }^{83}$ In that way, the estate of the first decedent spouse may defer both state and federal estate taxes until the surviving spouse dies.

For example, when a state has a $\$ 1$ million estate tax exemption and the federal government has a $\$ 5$ million estate tax exemption, by means of the state-only QTIP election, when permitted, the executor may sever the by-pass trust into two trusts: one containing $\$ 1$ million, which would use both the federal and state estate tax exemptions, and one containing $\$ 4$ million, which would be a by-pass trust for federal estate purposes. That technique would allow the use of the remaining

79. Economic Growth and Tax Relief Reconciliation Act of 2001, Pub. L. 107-16, $\S 532(d), 115$ Stat. 38, 73 (codified as amended at I.R.C. $\$ \S 2011,2058$ (2006)) (repealing credit for state death taxes and replacing them with deductions). The 2001 Act provided for a phase-out of the credit, allowed a partial credit for decedents dying between 2002 and 2004 and for decedents dying after 2004, and provides for a deduction for state death taxes. Economic Growth and Tax Relief Reconciliation Act of 2001, Pub. L. 107-16, § 531, 115 Stat. 38, 72-73 (codified as amended at I.R.C. $\S \S 2011,2058(2006)$ ).

80. See Jeffrey A. Cooper, Ghosts of 1932: The Lost History of Estate and Gift Taxation, 9 FLA. TAX REV. 875, 903 (2010) ("[I]n the last decade, efforts to maximize estate tax revenue have led many state legislatures to 'decouple' from the Federal estate tax regime and reduce state estate tax exemptions below the federal level.").

81. Id.; see also Ronald D. Aucutt, Estate Tax Changes Past, Present and Future, MCGUIREWOODS LLP, 5, http:/www.mcguirewoods.com/news-resources/publications/ estate-tax-changes.pdf (last updated Aug 8, 2011) (explaining the impact on states that decoupled their tax systems after 2001); 2011 State Death Tax Chart, MCGUIREWOODS LLP, http:/www.mcguirewoods.com/news-resources/publications/ taxation/state_death_tax_chart.pdf (last updated July 7, 2011) (cataloging each state's death tax laws)

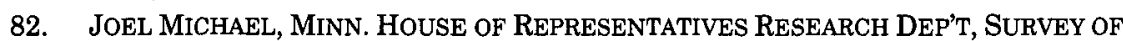
STATE ESTATE, INHERITANCE, AND GIFT TAXES 11, 13 (2010), available at http://www.leg.state.mn.us/docs/2010/other/101293.pdf.

83. See Stephen C. Hartnett \& Dennis M. Sandoval, Reports of Its Death Are Greatly Exaggerated: The State Death Tax Lives On, 6 J. PRAC. EST. PLAN. 31, 35-36 (2004) (demonstrating how to utilize a state QTIP independent of a federal QTIP). 
$\$ 4$ million of federal estate tax exemption. At the same time, the executor would make a state-only QTIP election so that the $\$ 4$ million would not be taxed for state estate tax purposes because it would qualify for the marital deduction for the state estate tax only. That type of estate planning is similar to the reverse QTIP election described in the preceding section, where there is a different amount of exemption available between the GST tax exemption and the unified tax credit applicable to estate and gift $\operatorname{tax}$.

With the ability to sever PAT trusts and the ability to make a partial PAT election for the trust not to qualify for the federal marital deduction, states should easily be able to create state-only PAT elections to enable that elected-out part of the PAT nevertheless to qualify for the state's estate tax marital deduction.

\section{A Clayton Contingent QTIP Election}

In Estate of Clayton v. Commissioner, decedent created both a trust, which was drafted with the intention of qualifying for QTIP treatment, and a credit shelter trust, which purposely was created so as not to qualify for the marital deduction. ${ }^{84}$ The marital deduction trust gave the widow a QTIP qualifying income interest in the property, but only if the trustee so elected. In Clayton, if no election had been made, however, the widow would have had no interest in that trust and the property would pass to the decedent's children from his first marriage. The Fifth Circuit held that the marital trust was a valid QTIP trust despite the fact that the widow's income interest was subject to a contingency. The court held that because the executor in fact made a QTIP election, preserving her interest, the election related back to the decedent's death, eliminating the contingency.

The Clayton contingent QTIP trust is the most popular form of the QTIP. ${ }^{85}$ It enables the executor to choose whether any interest in the trust should pass to the surviving spouse. With a PAT election, however, the surviving spouse herself would elect

84. Estate of Clayton v. Comm'r, 976 F.2d 1486, 1487-88 (5th Cir. 1992). Although the trust gave the widow a life interest in the income, she was also given an inter vivos special power of appointment to distribute the property to decedent's children from his first marriage. Because the QTIP provisions specifically prohibit appointing the property to anyone other than the surviving spouse during her lifetime, the trust could not qualify under any of the marital deduction provisions. I.R.C. § 2056(b)(7)(B)(ii)(II) (2006).

85. See Fax \& Cohn, supra note 19, at 46 (noting that the Clayton QTIP trust's popularity grew upon the enactment of the Economic Growth and Tax Relief Reconciliation Act of 2001). 
whether and to what extent the PAT should qualify for the marital deduction so that there would be no need for this minimal ownership marital deduction device.

\section{E. The Marital-Charitable Trust Combination}

The Code provides a marital deduction for the surviving spouse's qualifying income interest in a charitable remainder trust (CRT) with the surviving spouse as the only noncharitable beneficiary of the annuity or unitrust interest. ${ }^{86}$ If a trust qualifies for a marital deduction under this provision, there can be no QTIP election with respect to the trust. ${ }^{87}$ The surviving spouse's annuity or unitrust interest can be for her life or for a term of years not greater than twenty years. ${ }^{88}$ Where the surviving spouse is not the only noncharitable beneficiary, such as where, at her death, the decedent's son has a life interest in the trust, the trust must qualify under the QTIP provisions. In that case, the trust is entitled to a marital deduction despite the fact that her son, a third party, has a life interest in the trust. ${ }^{89}$

This is a popular device that carries great support, not surprisingly, from charities..$^{90}$ However, in line with this Article's

86. I.R.C. \& 2056(b)(8) (2006). Section 2056(b)(8) provides:

(A) In general

If the surviving spouse of the decedent is the only beneficiary of a qualified charitable remainder trust who is not a charitable beneficiary nor an ESOP beneficiary, paragraph (1) shall not apply to any interest in such trust which passes or has passed from the decedent to such surviving spouse.

(B) Definitions

For purposes of subparagraph (A)-

(i) Charitable beneficiary

The term "charitable beneficiary" means any beneficiary which is an

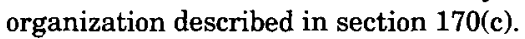

(ii) ESOP beneficiary

The term "ESOP beneficiary" means any beneficiary which is an employee stock ownership plan (as defined in section 4975(e)(7)) that holds a remainder interest in qualified employer securities (as defined in section $664(\mathrm{~g})(4))$ to be transferred to such plan in a qualified gratuitous transfer (as defined in section $664(\mathrm{~g})(1)$ ).

(iii) Qualified charitable remainder trust

The term "qualified charitable remainder trust" means a charitable remainder annuity trust or a charitable remainder unitrust (described in section 664).

Id. Under the statute and regulations, the income interest would not be a nondeductible terminable interest and would thus be eligible for the marital deduction. Id.

87. Treas. Reg. $\$ 20.2056(\mathrm{~b})-8(\mathrm{a})(1)(1994)$.

88. Treas. Reg. $\$ 20.2056(\mathrm{~b})-8(\mathrm{a})(2)(1994)$.

89. Treas. Reg. $\$ 20.2056(b)-(8)$ (b) (1994).

90. See, e.g., Q-TIP Trust, LAWRENCE UNIVERSITY, 
proposal to repeal the QTIP provisions, the marital deduction should not be available where there are additional noncharitable beneficiaries. Where the surviving spouse is the sole noncharitable beneficiary of a CRT and where she, and not the executor, would be the one eligible to make an election at decedent's death for the remainder to pass to the charity at her death, this arrangement may sufficiently resemble a PAT to argue for a combined marital and charitable deduction for the full value of the trust at the decedent's death. If the surviving spouse does not make the election, the charitable deduction rules relating to CRTs involving nonspousal, noncharitable beneficiaries should apply. ${ }^{91}$

Opposed to this position is the argument that the surviving spouse would merely be exercising a limited power of appointment and not a general one as required for a PAT. ${ }^{92}$ While the long-standing (and cherished) distinction between general and limited powers of appointment would suggest disallowing such an exception, ${ }^{93}$ it would be the couple and not merely one spouse making that choice. Thus, while I have some misgivings about this combination qualifying for a marital deduction, ${ }^{94} \mathrm{I}$ agree that the two types of powers of appointment may not be essentially very different. ${ }^{95}$ The surviving spouse's income

http://morelight.lawrence.edu/OtherGiftsQtip.aspx (last visited Aug. 28, 2011) ("A Qualified Terminable-Interest Property trust provides a high degree of flexibility in providing for a surviving spouse's needs and subsequently benefiting a charity. In this arrangement, a trust is created by will for the benefit of the surviving spouse. The trustee is empowered to distribute income to the spouse, and to invade the trust corpus if necessary, to maintain lifestyle or cover medical or other costs as they may arise. Any remaining assets are then distributed to charity as specified in the trust. The full estate tax marital deduction is available, as is an estate tax charitable deduction in the spouse's estate.").

91. See I.R.C. $\$ 664$ (2006) (discussing charitable remainder trusts); I.R.C. $\S 2055(\mathrm{e})(2)(\mathrm{A})(2006)$ (disallowing deductions for remainder interests unless the interest is a charitable remainder annuity trust, charitable remainder unitrust, or pooled income fund).

92. See supra note 86 (describing a charitable remainder trust as one that specifies a charity or as ESOP as the remainder beneficiary); JESSE DUKEMINIER, ROBERT H. SitKoff \& JAMES LindGREN, Wills, TRUSTS, AND EsTates 804-05 (8th ed. 2009) (explaining that a limited power of appointment exists when the trust limits the beneficiaries and the donee cannot exercise that power in favor of herself or her creditors).

93. Exercising a limited power of appointment does not create any tax consequences. Possessing, exercising, or releasing a general power of appointment, however, is a taxable event. See I.R.C. $\$ \S 2041,2514$ (2006) (explaining that exercise of power of appointment that results in a transfer of property is includable in the decedent's gross estate).

94. The surviving spouse does not select the ultimate beneficiary of the trust property; rather, her only choice is to accede to the charitable beneficiary named by the decedent. See I.R.C. $\$ 664$ (d) (2006). By contrast, the surviving spouse would have an unlimited choice of beneficiaries under a general power of appointment sufficient to qualify under a super-charged PAT.

95. A limited power of appointment may be drafted to include a very expansive list 
interest would likely be more significant where the charity is the remainderman, ${ }^{96}$ and the ultimate decision for qualifying for the marital deduction would rest with the surviving spouse. ${ }^{97}$ Therefore, on balance, this Article recommends retaining this option with these proposed amendments.

\section{OUTRIGHT BEQUEST OR A TRUST?}

\section{A. Outright Transfer}

1. Benefits of Outright Transfer. Certainly, the easiest intraspousal transfer is an outright gift or bequest. There are no attorney's fees or administration costs such as those typically accompanying a trust. ${ }^{98}$ The property ownership is complete, and so the spouses had or have the same rights and powers over "their" property. Outright ownership by the surviving spouse reflects the most confidence and trust in a marriage relationship. It allows the surviving spouse to make decisions based on facts that occur after the decedent's death and, in that respect, affords the marital unit with the greatest ability to adapt to later events.

2. Comparison with the Flexibility of a QTIP Trust. A QTIP trust is favored with the ability to elect marital deduction status. To the extent that QTIP treatment, however, is not elected, the transfer does not qualify for the marital deduction and therefore is taxed in the decedent's estate in order to form a by-pass trust equal to the decedent's remaining transfer tax credit. ${ }^{99}$ Even with portability, ${ }^{100}$ there is an advantage to creating a by-pass trust, which does not qualify for the marital deduction, in order to shelter that trust from transfer taxes on any appreciation

of potential beneficiaries and thus may not in fact be very different from a general power of appointment. See DUKEMINIER, SITKOFF \& LINDGREN, supra note 92, at 804 (explaining why a general power of appointment is not necessarily broader than a limited power of appointment, depending on drafting).

96. Typically, a QTIP involves children from a previous marriage as the remaindermen of the trust, and that often creates conflicts; by contrast, a charity usually wants to encourage donations and, as a tax-exempt entity, may produce higher income yields.

97. One of the central features of the super-charged PAT is to give the surviving spouse the power to make a marital deduction election (in or out). See infra Part XI.

98. Where a family member is the trustee, they may serve without compensation; however, there are still attorney's fees involved in creating a trust. Moreover, over the course of a trust or in instances to prevent a conflict of interest, professional trust management is common.

99. I.R.C. § 2056(b)(1)(A) (2006); Herbert L. Zuckerman \& Jay A. Soled, Funding Testamentary Trusts on the Death of the First Spouse, EXPERIENCE, Winter 1996, at 35, 35.

100. See infra Part VII. 
between the couple's deaths.

An outright transfer to one's spouse automatically qualifies for the marital deduction. If the surviving spouse were given an election not to treat some of those outright gifts as qualifying for the marital deduction, those items would be taxed in decedent's estate and would be available to absorb the remaining estate tax exemption. However, unlike with a trust, there would be no mechanism with an outright gift to ensure that portion would not later, at least to the extent of asset appreciation, be taxed in her estate. ${ }^{101}$

To avoid tracing issues, it would seem that any election for an outright spousal transfer to be taxed in decedent's estate, rather than in the surviving spouse's estate, would have to be made as a fixed dollar amount (the asset's value at decedent's death) because the asset could be sold and replaced, perhaps many times, between the couple's two deaths. ${ }^{102}$ If her election was restricted to a fixed-dollar amount, however, the surviving spouse would lose at least some of the benefit of the property passing to her being taxed at decedent's death and not again subject to tax at the surviving spouse's subsequent death-that is, any post-death appreciation during that period would not be sheltered as in a by-pass trust. That dollar amount should be indexed for inflation to solve that problem, but because there is a certain amount of maneuvering done by the executor's choice of assets funding the by-pass trust ${ }^{103}$ a QTIP trust would probably still provide the couple with a somewhat greater transfer tax savings.

Like portability, this type of election "out" would effectively increase the surviving spouse's exemption when she later died to reflect that the fixed, indexed amount had already been taxed in

101. See Don W. Llewellyn, Kenneth J. Levin \& Gail Levin Richmond, Computing the Optimum Marital Deduction: Is a Zero-Tax Formula Appropriate?, 24 REAL Prop. PRoB. \& TR. J. 331, 338-40 (1989) (exploring the consequences of different tax reduction strategies on the ultimate amount of estate tax a couple will pay). If the asset remained in the surviving spouse's estate, you could exclude that asset from her estate; however, if the asset were sold sometime between the couple's deaths, tracing would be a complexity and, often, a problem. See Hazel de Burgh, Strategies for Tracing and Recovering Missing Assets, 15 EST. \& TR. J. 265, 279 (1996) (outlining tools and techniques to recover missing assets).

102. See de Burgh, supra note 101, at 268, 279 (explaining that a periodic accounting of all assets in a trust is required, so that all purchase prices, gains, and losses are traceable).

103. Although the executor is restricted by Rev. Proc. 64-19, 1964-1 C.B. 682, there is some flexibility in funding the marital and by-pass trusts. See Christopher Hoyt, Funding Bypass Trusts with Retirement Assets, PROB. \& PROP., May-June 2004, at 10, 11, 13-15 (demonstrating various methods to fund by-pass trusts). 
the decedent's estate. ${ }^{104}$ Unlike portability, however, the executor would not need to elect to preserve the decedent's unused credit amount. Rather, it should be the surviving spouse who would be empowered to make that marital unit decision. And, unlike portability but like a by-pass trust, under this proposal, her estate would have that fixed-dollar amount indexed for the inflation between decedent's death and her own death or earlier transfer. ${ }^{105}$

\section{B. A Trust}

Both a PAT and a QTIP trust are trusts and are thus both very flexible devices. ${ }^{106}$ In general, trusts offer professional management and privacy because trusts are centrally managed by the trustee and they are not subject to probate costs or administration. ${ }^{107}$ Trusts also offer the benefits of management in case of the beneficiary's incompetency or minority and can provide for spendthrift protection or discretionary payments. ${ }^{108}$

Spendthrift provisions "prevent a beneficiary from alienating his own interests in trust assets through pledging those interests, or the trust assets themselves, for the benefit of his creditors." ${ }^{109}$ However, they are "to be distinguished from other trusts... [that] protect... by providing for a termination or forfeiture of the trust estate, for discretion in a trustee as to the outgo of benefits from a trust estate to beneficiaries, or other similar devices."110 A QTIP trust can be a spendthrift trust, ${ }^{111}$

104. See supra Part V.A-D (discussing elections in QTIP trusts).

105. The current portability measures in 2011 do not provide for that advantage. See I.R.C. $\$ 2010$ (2006) (providing a fixed credit amount that varies according to the year decedent died). Although the $\$ 5$ million exemption will be increased in 2012 to reflect an inflation adjustment, she would also be able to exclude more because she would have both a larger exemption and a larger exclusion for amounts already taxed in the decedent's estate. Tax Relief, Unemployment Insurance Reauthorization, and Job Creation Act of 2010, Pub. L. No. 111-312, § 303, 124 Stat. 3300, 3302-03 (to be codified at I.R.C. § 2010 (2006)).

106. See, e.g., DUKEMINIER, SITKOFF \& LINDGREN, supra note 92, at 543, 554-55 (explaining diverse uses for trusts and superiority of trusts over a legal life estate).

107. Id. at $440,543$.

108. Id. at 543,614 .

109. Miller v. United States, 949 F. Supp. 544, 545 (N.D. Ohio 1996); DUKEMINIER, SITKOFF \& LINDGREN, supra note 92, at 614; see UNIF. TRUST CODE \$\$ 502, 503, 7C U.L.A. 523-25 (2006) (providing exceptions to spendthrift provisions). Spendthrift trusts are enforceable in all U.S. jurisdictions. See DUKEMINIER, SITKOFF \& LINDGREN, supra note 92 , at 616 (discussing recognition of spendthrift trusts).

110. Miller v. United States, 267 F. Supp. 326, 331 n.4 (M.D. Fla. 1967) (internal quotation marks omitted).

111. See id. at 331 ("The government, in effect, concedes that a mere spendthrift provision is not such a limitation that would cause this gift to fail to meet the requirement that the life tenant be entitled to income." (footnote omitted)); I.R.S. Tech. Adv. Mem. 
offering the surviving spouse debtor protection; a PAT may also offer that protection to her. ${ }^{112}$ While both trusts may be discretionary trusts to the extent that the discretionary payments or powers exceed those required by statute for qualifying each trust for the marital deduction, they may not be discretionary trusts that could diminish the surviving spouse's required interests or powers. ${ }^{13}$ Periodically, the government has contested the ability of an income interest subject to a spendthrift provision to qualify for the marital deduction. ${ }^{114}$ The argument is that the surviving spouse does "not have an unqualified right to all the income from the marital trust assets, because her right to the income was circumscribed by the spendthrift provisions."115 However, courts have generally favored the allowance of the marital deduction where a QTIP ${ }^{116}$ or PAT $^{117}$ income interest was subject to a boilerplate spendthrift clause. The conflict is often resolved by rules of statutory construction, with the marital trust as "a specific, affirmative dispositive provision" trumping the spendthrift clause, which is "a general, non-dispositive provision." 118

There is case law and other authority holding that the general power of appointment in a PAT that has a spendthrift

85-32-006 (Apr. 19, 1985), available at 1985 WL 294289 (stating that a spendthrift provision in a trust would not disqualify such a trust from the marital deduction). Treas. Reg. $\S 20.2056(\mathrm{~b})-7(\mathrm{~d})(2)$ (as amended in 2004) (QTIP) refers to Treas. Reg. $\$ 20.2056(\mathrm{~b})-5(\mathrm{f})(7)$ (as amended in 2004) (PAT), which provides, in part: "An interest passing in trust will not fail to satisfy the condition that the spouse be entitled to all the income merely because its terms provide that the right of the surviving spouse to the income shall not be subject to assignment, alienation, pledge, attachment or claims of creditors." Treas. Reg. $\S 20.2056$ (b)-5(f)(7) (as amended in 2004).

112. Miller, 267 F. Supp. at 331-32; see Ira Mark Bloom, Powers of Appointment Under the Restatement (Third) of Property, 33 OHIO N.U. L. REV. 755, 779-80 (2007) (discussing creditor protection provided by a power of appointment). However, creditors may reach the income stream from both types of marital trusts and therefore may take from her whatever assets are in fact paid to her since, once paid, they are no longer subject to the trust. Id. at 332 .

113. See id. (noting that the surviving spouse must maintain the right to dispose of her estate and receive income).

114. Miller, 949 F. Supp. at 544-45.

115. Id. at 546.

116. See id. at 545,548 (holding that a marital trust containing a spendthrift provision still qualifies for the marital estate tax deduction).

117. See Va. Nat'l Bank v. United States, 307 F. Supp. 1146, 1150-51 (E.D. Va. 1969) (finding a PAT containing a spendthrift provision to meet the requirements of the marital deduction).

118. Miller, 949 F. Supp. at 547; see also Va. Nat'l Bank, 307 F. Supp. at 1148 ("The well established rule of construction is 'that the terms or language necessary to rescind or cut down an estate previously created and given must be at least as clear and decisive as the terms or language by which the estate was previously created." (quoting Moore v. Holbrook, 9 S.E.2d 447, 450 (Va. 1940)). 
provision qualifies for the marital deduction; ${ }^{119}$ however, there is also more recent authority suggesting otherwise. ${ }^{120}$ The QTIP, which may confer on the surviving spouse a special power of appointment, provides debtor protection as a special power of appointment that is not equated with ownership. ${ }^{121}$ Likewise, a PAT, which must give the surviving spouse a general power to appoint the trust property to herself or to her estate, provides the surviving spouse with the same debtor protection in jurisdictions that follow the traditional rule; that is, while a general power of appointment is considered ownership for tax purposes, it is not considered ownership for creditor purposes. ${ }^{122}$ In jurisdictions that follow the modern rule, however, creditors may reach the appointed property. ${ }^{123}$ The modern rule is based on the

119. See Miller, 949 F. Supp. at 547-48 (holding that a marital trust containing a spendthrift provision still qualifies for the marital estate tax deduction); I.R.S. Priv. Ltr. Rul. 89-40-009 (Oct. 6, 1989) (advising that a spendthrift clause in a trust will not preclude application of marital deductions). For example, Colorado allows creditor protection for PATs. "Spendthrift protections can be afforded the surviving spouse even if the survivor is given a general power of appointment over the trust. Colorado courts have recognized that the donee of such a power cannot be compelled to exercise it, nor may creditors acquire it." Bette Heller, Ken Ransford \& Carl Stevens, Joint Revocable Trusts, Colo. LAw., Aug. 1997, at 63, 64-65. Also, in Corey v. National Bank of Toledo, the court held that the surviving spouse's bequest qualified for the marital deduction because the specific language in the will stated that the income payable must be at least that amount required to qualify for the marital deduction and prevailed over the general spendthrift provision in the trust, which the court held did not apply to the marital bequest. Corey $\mathrm{v}$. Nat'l Bank of Toledo, 159 N.E.2d 814, 817-18 (C.P. Lucas Cnty. Ohio 1958).

120. See, e.g., I.R.S. Tech. Adv. Mem. 20-05-022 (Feb. 4, 2005) (advising that the trust in question, which contained a spendthrift clause, did not qualify for the marital deduction because the surviving spouse did not have an unqualified right to the trust income).

121. See Bloom, supra note 112, at 779-80 (considering broad special powers of appointment virtually identical to ownership).

122. See Irwin Union Bank \& Trust Co. v. Long, 312 N.E.2d 908, 913 (Ind. Ct. App. 1974) (stating the donee of a general power of appointment "has no control over the trust corpus until he exercises his power of appointment and gives notice to the trustee that he wishes to receive his $4 \%$ of the trust corpus" and "[u]ntil such an exercise is made, the trustee has the absolute control and benefit of the trust corpus within the terms of the trust"). Thus, because an unexercised general power of appointment does not constitute ownership, and there was no state statute providing to the contrary, a creditor of the holder of the power cannot reach the trust property covered by the power of appointment.

123. See UNIF. TRUST CODE $\$ 505(\mathrm{~b})$ (amended 2000), 7C U.L.A. 523-25 (2006) (equating the holder of a power of withdrawal to the settlor of a revocable trust); RESTATEMENT (THIRD) OF TRUSTS $\S 56 \mathrm{cmt}$. b (2003) (treating the trust property as if owned by the settlor for purposes of creditors' rights). Both rules treat the donee of the power of appointment as the settlor of a revocable trust, effectively making the power holder the owner. $C f$. UNIF. PROBATE CODE $\$ 1-403$ (amended 1993) (distinguishing a power of revocation from a general power of appointment and denominating only the latter ownership). In some jurisdictions, creditors may only reach inter vivos general powers of appointment, but not testamentary ones. However, the Restatement considers both types of general powers of appointment reachable by creditors of the donee where the donee's other assets are insufficient. See RESTATEMENT (THIRD) OF PROPERTY: WILLS AND 
equivalence of the general power and ownership. ${ }^{124}$ Whether the traditional or modern rule applies is a matter of state law, but that might well dictate whether a PAT with a spendthrift provision satisfies the requirement of the marital deduction.

\section{PORTABILITY}

At the end of 2010, Congress enacted limited portability of the unused estate tax exemption amount from a decedent to his surviving spouse. By that provision, the surviving spouse not only has her exemption amount but added to that is her deceased spouse's unused exemption. ${ }^{125}$ The surviving spouse may apply the additional exemption amount both to lifetime and testamentary transfers.

Portability of the deceased spouse's unused estate tax exemption is not an issue involving the marital deduction, but of utilizing the couple's maximum combined estate tax exemption equal to the couple's unified credit. ${ }^{126}$ Portability of exemptions is most helpful to those couples with combined estates of $\$ 10$ million or less, but relying on portability is unwise if the couple wants to shelter the asset appreciation occurring between the two spouses' deaths. ${ }^{127}$

OTHER Donative Transfers $\S 22.3$ (Tentative Draft No. 5, 2006); Bloom, supra note 112, at 782-84 (discussing the departure from previous Restatements allowing creditors to reach property over which the donee had exercisable powers only if permitted by state law).

124. Bloom, supra note 112, at 783. Professor Bloom interprets the new Restatement (Third) of Property rule to provide that creditors will be able to reach the surviving spouse's general power of appointment in a PAT. Id. at 786. Moreover, he anticipates that trusts will be created in jurisdictions that have asset protection statutes for general powers of appointment.

125. Tax Relief, Unemployment Insurance Reauthorization, and Job Creation Act of 2010, Pub. L. No. 111-312, § 303, 124 Stat. 3296, 3302 (to be codified at I.R.C. $\S 2010$ (c) (2006)). Under the amended $\S 2010$ (c), her additional exclusion amount is defined as "the lesser of - (A) the basic exclusion amount, or (B) the excess of-(i) the basic exclusion amount of the last such deceased spouse of such surviving spouse, over (ii) the amount with respect to which the tentative tax is determined under section 2001(b)(1) on the estate of such deceased spouse." Id. The executor of the deceased spouse must have filed a timely estate tax return and made an irrevocable election specifically allowing the surviving spouse to use the decedent's unused exclusion amount. See JOINT COMM. ON TaXation, Technical Explanation of the Revenue Provisions Contained in the “TAX RELIEF, UNEMPLOYMENT INSURANCE REAUTHORIZATION, AND JOB CREATION ACT OF 2010" SCHEDULED FOR CONSIDERATION BY THE U.S. SENATE 52 (2010) (explaining the ability of a surviving spouse to use the predeceased's unused exclusion).

126. JOINT COMMTTTEE ON TAXATION, supra note 125, at 51-52; Mitchell M. Gans, Jonathan G. Blattmachr \& Austin Bramwell, Estate Tax Exemption Portability: What Should the IRS Do? And What Should Planners Do in the Interim?, 42 REAL PROP. PROB. \& TR. J. 413, 416 (2007).

127. To shelter that appreciation, the decedent still must use a credit shelter or by-pass trust. See Robert A. Dawkins, Another Bite at the Apple: Using the Alternate Valuation 
The negative election or "election-out" proposal in this Article, which would be available to outright spousal gifts or to transfers to a PAT, would mimic portability in several respects. It would enable the first spouse to transfer an ownership interest to the surviving spouse, who would automatically qualify for the marital deduction, not to qualify for that benefit. That is, she could elect to have some of the property taxed at the decedent's death, despite that she actually owned the property in the trust through her general power of appointment, and not taxed when she dies or earlier when she gives the property to a third party. She might want to make this "election-out" where there was no by-pass trust or, if lower brackets return, to equalize each spouse's estate and thereby minimize their aggregate tax liability.

Furthermore, the surviving spouse would have the power to make that election regardless of whether she was the executor, ${ }^{128}$ and she would effectively own the trust property until it left the marital unit. ${ }^{129}$ If the decedent wanted to ensure that his children got the property, he would have to pay estate or gift taxes at his death or earlier transfer; by contrast, if he trusted his spouse to make a third party transfer at her death, he could defer current transfer taxes. ${ }^{130}$

\section{DISCLAIMER OR SUPER-CHARGED PAT?}

Disclaimers are traditionally used in estate planning to provide postmortem flexibility. ${ }^{131}$ In order to constitute a qualified disclaimer for transfer tax purposes, the taxpayer must follow

Election to Restore a Credit Shelter Trust, PROB. \& PROP., Jan.-Feb. 2002, at 28, 28 (explaining how a credit shelter trust can increase in value under the pecuniary marital formula). Additionally, there is no portability of the GST tax exemption; thus, to make full use of each spouse's GST tax exemption amount, the couple still needs estate planning.

128. The QTIP and portability of exemption elections, by contrast, can only be made by the decedent's executor. See I.R.C. $\$ 2056(\mathrm{~b})(7)(\mathrm{B})(\mathrm{v})(2006)$.

129. See supra Part VI.A.1 (discussing the benefits of outright transfer); RESTATEMENT (THIRD) OF TRUSTS $\S 56 \mathrm{cmt}$. b (2003) (equating the power of appointment with outright ownership).

130. This is, of course, unless the surviving spouse, generally for tax reasons, elected to pay the tax at his death rather than later at her death (an "election-out" under the proposal in this Article).

131. Disclaimers provide postmortem flexibility because they can be used for numerous purposes, as determined by facts available after the decedent's death. Those uses include, for example, creating interests that would qualify for the marital deduction; creating interests that would not qualify for the marital deduction that would be used to fund a by-pass trust; creating or funding a dynasty trust to use GST tax exemption; or enabling an estate to use favorable valuation statutes like I.R.C. $\S 2032$ (the alternate valuation date election) or $\S 2032 \mathrm{~A}$ (special use valuation of farms and real estate of closely held businesses). I.R.C. $\$ \S 2032,2032 \mathrm{~A}(2006)$. 
many specific statutory requirements. ${ }^{132}$ For example, the disclaimer must be in writing, ${ }^{133}$ received by the transferor or certain fiduciaries within nine months of the creation of the interest or within nine months of the disclaimant's twenty-first birthday, ${ }^{134}$ the disclaimant must not have received any of the benefits of the property, ${ }^{135}$ and the property must pass either to the decedent's spouse or to another who would take without any direction by the disclaimant. ${ }^{136}$

Although disclaimers are used postmortem, the decedent generally directs in his will where the property will pass. ${ }^{137}$ That said, the decedent's intended disclaimant may choose not to disclaim if she wants the property or wants to control its disposition. ${ }^{138}$ Indeed, disclaimer planning is used where the decedent does trust his surviving spouse to disclaim for estate tax reasons or where she has determined that she has sufficient, independent personal wealth of her own. ${ }^{139}$ With the supercharged PAT, by contrast, it is the surviving spouse who would determine the third party beneficiaries who would receive the property at her death or earlier transfer. ${ }^{140}$ That, however, is not to say that she would not transfer the property to those beneficiaries suggested in the decedent's will.

The benefits of allowing a partial election of the marital deduction as compared to making a partial disclaimer of her interest are that the super-charged PAT process is much easier to comply with than a qualified disclaimer ${ }^{141}$ and gives the

132. I.R.C. $\S \S 2046,2518(2006)$.

133. I.R.C. § $2518(\mathrm{~b})(1)(2006)$.

134. I.R.C. $\$ 2518(\mathrm{~b})(2)(\mathrm{A})-(\mathrm{B})(2006)$.

135. I.R.C. $\S 2518(\mathrm{~b})(3)(2006)$.

136. I.R.C. $\$ 2518(\mathrm{~b})(4)(\mathrm{A})-(\mathrm{B})(2006)$. In order to provide for a uniform rule, I.R.C. $\S 2518$ (c)(3) provides that a written transfer of the entire interest that meets the requirements of Section 2518 (b)(2)-(3) will be treated as a qualified disclaimer. I.R.C. $\S 2518(\mathrm{c})(3)(2006)$.

137. David Westfall \& George P. Mair, Estate Planning Law and Taxation II 15.08 , at $15-32$ (4th ed. 2011).

138. Id. II 15.08[2][a], at 15-38 to -39.

139. William Schwartz, Effective Use of Disclaimers: Frustrating the Planner and Federal Tax Policy, 19 B.C. L. REv. 551, 554-56 (discussing disclaimer planning).

140. That is, she will determine the beneficiaries unless she does not exercise her power of appointment. In that case, the property will pass to the takers in default as generally provided by the decedent or will revert to the decedent's estate.

141. A qualified disclaimer has many requirements that must each be satisfied; an "election-out" requires merely a check in the appropriate box on the decedent's estate tax return. Compare I.R.C. $\$ 2518$ (2006) (outlining the steps required to obtain a qualified disclaimer), with I.R.S. Form 706, Schedule M (rev. Sept. 2009), available at http://www.irs.gov/pub/irs-pdf/f706.pdf (instructing the tax filer to check a box to elect out of QTIP treatment of annuities). For example, regarding the time to disclaim, for a 
surviving spouse more time to decide what to do with the property. ${ }^{142}$ To the extent of a PAT election-out, the surviving spouse would have her full PAT interest and powers. The property taxed at decedent's death would not be taxed again when the surviving spouse exercises or releases her general power of appointment. By contrast, a disclaimer inherently requires the surviving spouse to diminish her interest. ${ }^{143}$

\section{EleCtions-in/OUT IN FAMILy LaW TAX PLANNING}

At least from the $1980 \mathrm{~s}$, ${ }^{144}$ there has been an emphasis on allowing married taxpayers to arrange their domestic relation tax planning. ${ }^{145}$ "Private ordering" was the term used by those

qualified disclaimer, the disclaimant must disclaim within nine months of the creation of the interest. If the transfer involves the creation of both a present and a future interest, such as a life interest and a remainder, the disclaimer clock begins to run on that remainder interest at the creation of the remainder and not on its possession. I.R.C. $\S 2518$ (b) (2006).

142. An election-out would need to be made by the time for filing the decedent's estate tax return, including extensions. While decedent's estate tax return is officially due nine months after decedent's death, the estate is generally entitled to an automatic six month extension and, thus, there are fifteen months (rather than the disclaimer nine months) to determine the efficacy of various elections. See I.R.C. $\$ 6075$ (a) (2006) (requiring returns to be filed within nine months of decedent's death); Treas. Reg. $\S 20.6081-1$ (b) (2001) (providing for an automatic six-month extension beyond the time allotted by I.R.C. $\$ 6075(\mathrm{a})$ ).

143. While the disclaimer provisions allow the property to benefit the surviving spouse after a disclaimer, retaining more than an income interest, such as an interest in the underlying property itself, will undo the benefits of making the disclaimer in the first place (such as where the surviving spouse is disclaiming in order to create a taxable estate). See I.R.C. $\$ 2518(\mathrm{~b})(4)$ (A)-(B) (2006) (providing that after a qualified disclaimer is made a person may accept an interest in the property but only if the interest passes to the spouse of the decedent or to a person other than the person making the disclaimer).

144. While taxpayer elections have existed at least since the 1930 s with the option to select alternate valuation date values for assets included in the taxpayer's estate, the alternate valuation date election can only be made where the election would decrease both the value of decedent's gross estate and his estate (and GST) tax liability. See I.R.C. $\S 2032$ (a)-(c) (2006) (allowing decedent's property to be valued within six months of decedent's death provided that the election decreases the value of the gross estate); Revenue Act of 1935, Pub. L. No. 74-407, § 202(j), 49 Stat. 1014, 1022-23 (repealed 1939) (allowing decedent's property to be valued one year after decedent's death). Congress enacted Section 302(j) in response to "the hardships which were experienced after 1929 when market values decreased very materially between the period from the date of death and the date of distribution to the beneficiaries." 79 CONG. REC. 14,632 (1935) (statement of Rep. Samuel B. Hill); see also H.R. REP. No. 74-1681, at 9 (1935) (discussing the one-year valuation protection against net asset shrinkage); S. REP. No. 74-1240, pt. 1, at 9-10 (1935) (discussing the one-year valuation protection against net asset shrinkage); $\mathbf{S}$. REP. NO. 74-1240, pt. 2, at 8-9 (1935) (discussing the one-year valuation protection against net asset shrinkage).

145. See, e.g., Joseph N. DuCanto, A Client Letter: Divorce and Remarriage, A.B.A. J., Apr. 1, 1987, at $71,71-72,74$ (discussing the tax benefits to be reaped by strategically planning a divorce settlement). 
professionals, like those in the ABA Domestic Relations Tax Simplification Task Force, ${ }^{146}$ who advocated freedom of divorcing or separating parties to dictate the income tax consequences of their post-divorce or post-separation transfers. ${ }^{147}$ Despite the Treasury Department's concern with the inequity and public perception of abuse inherent in such private tax planning arrangements that would inevitably result in income shifting, ${ }^{148}$ the 1984 legislation embraced the private ordering concept in its definition of alimony. ${ }^{149}$ That legislation repealed the requirement that linked the definition of alimony to "a marital obligation imposed under local law." "150 Thus, support that fulfils a state law's definition of alimony does not have to be treated as alimony for federal income tax purposes.

Both the QTIP and the reverse QTIP elections that were enacted in 1981 allow private ordering of estate planning decisions. The QTIP election allows postmortem planning to defer transfer taxes until the second spouse's death. ${ }^{151}$ The reverse QTIP election allows the couple to make the most efficient use of their GST tax exemptions. ${ }^{152}$ The opt-in/opt-out nature of the combination of a QTIP/reverse-QTIP election permits the surviving spouse to become the third party transferor

146. See Domestic Relations Tax Simplification Task Force, Am. Bar Ass'n, The "Private ORDERING" CONCEPT IN PROPOSALS FOR Simplification OF Domestic RELATIONS TAX LAW 1-5 (1982) (advocating for the federal government to adopt private ordering in divorce settlement taxation).

147. ABA Task Force Favors 'Private Ordering' for Divorced Spouses, 16 TAX NOTES 839, 839 (1982); see Marci Kelly, Calling A Spade a Club: The Failure of Matrimonial Tax Reform, 44 TAX LAW. 787, 811-12 (1991) (providing examples of private ordering in action and discussing its advantages); Laurie L. Malman, Unfinished Reform: The Tax Consequences of Divorce, 61 N.Y.U. L. REv. 363, 387-88, 399-400 (1986) (discussing congressional adoption of the concept of private ordering for divorce in modern tax law).

148. See Tax Law Simplification and Improvement Act of 1983: Hearing on H.R. 3475 Before the H. Comm. on Ways and Means, 98th Cong. 152-53 (1983) (statement of Ronald A. Pearlman, Deputy Assistant Secretary (Tax Policy), Department of the Treasury) (opposing complete elimination of periodic alimony payment requirement and ten year rule requirement); Lee A. Sheppard, 'Safe Harbor' Divorce Under the 1986 Act, 33 TAX NOTES 531, 531-32 (1986) (recounting the legislative hearings and debates that resulted in legislation adopting private ordering for alimony taxation).

149. See Deficit Reduction Act of 1984, Pub. L. No. 98-369, § 422(a), 98 Stat. 494, 795 (codified at I.R.C. $\$ 71(2006)$ ) (providing flexibility by defining alimony as including instances where "the divorce or separation instrument does not designate such payment as a payment which is not includible in gross income under this section and not allowable as a deduction under section 215”); Temp. Treas. Reg. § 1.71-1T(a), Q\&A (2), (8) (1984) (discussing the option of structuring a divorce settlement to transfer income taxation liability to either the payor or payee for post-separation payments).

150. H.R. REP. No. 98-432, pt. 2, at 194-95 (1984), reprinted in 1984 U.S.C.C.A.N. 1137-39.

151. See supra Part II (explaining how a QTIP operates).

152. See supra Part V.B (explaining how a reverse QTIP operates). 
for estate tax purposes (despite the decedent's in fact determining who will be the third party beneficiary) and at the same time allows the decedent to remain the transferor for GST tax purposes to the extent that he has not previously exhausted his GST tax exemption. ${ }^{153}$ Despite the illogic or conflicting identities created by allowing those elections, Congress has embraced such elections in modern family estate planning to achieve flexibility or private ordering. ${ }^{154}$ Thus, while the PAT "election-outs" may seem (and in fact are) contradictions to the essential nature of a PAT, they are no more peculiar than any of those other elections and they too would reflect other similar recent transfer tax trends.

With the enactment of Chapter 14 and its special valuation rules applicable to certain family gifts, ${ }^{155}$ there are additional recent opportunities that allow a taxpayer to elect in or out of a certain tax treatment. Specifically, a taxpayer can elect to have a nonqualified interest treated as a qualified interest or to have a qualified interest treated as a nonqualified interest. ${ }^{156}$ The consequence of an election-in is obviously to reduce the value of the taxpayer's gift since a qualified retained interest "counts" to reduce the amount of the gift transferred to a third party. ${ }^{157}$ The reason for an election-out is to enable a taxpayer, who fears she may be unable to make timely payments as required for a

153. See I.R.C. $\$ 2632(e)(1)$ (2006) (allocating any unused portion of an individual's GST exemption to GST property transfers and trusts); I.R.C. \& 2652(a) (2006) (allowing a reverse QTIP election to maximize the tax benefit of GST and estate tax exemptions by permitting the surviving spouse to act as a third party transferor).

154. See DODGE, GERZOG \& CRAWFORD, supra note 9, at 292 (explaining the private ordering that resulted after the passage of the 1981 tax reforms).

155. Omnibus Budget Reconciliation Act of 1990, Pub. L. No. 101-508, § 11602, 104 Stat. 1388, 1388-491 to -497 (codified at I.R.C. \$§ 2701-04 (2006)).

156. A qualified payment is defined as "any dividend payable on a periodic basis under any cumulative preferred stock (or a comparable payment under any partnership interest) to the extent that such dividend (or comparable payment) is determined at a fixed rate." I.R.C. $\& 2701$ (3)(A) (2006). The statute also provides for an election-out, where "[p]ayments under any interest held by a transferor which (without regard to this subparagraph) are qualified payments shall be treated as qualified payments unless the transferor elects not to treat such payments as qualified payments." I.R.C. $\$ 2701(3)(\mathrm{C})(\mathbf{i})$ (2006) (emphasis added). An election-in allows "[a] transferor or applicable family member holding any distribution right which (without regard to this subparagraph) is not a qualified payment [tol elect to treat such right as a qualified payment, to be paid in the amounts and at the times specified in such election." I.R.C. \$2701(3)(C)(ii) (2006) (emphasis added); see also Treas. Reg. $\S \S 25.2701-2$ (d) ex.5, 25.2701-4(d) (1992) (providing examples of how elections-in and elections-out function).

157. See I.R.C. $\$ 2701(\mathrm{c})(3)(\mathrm{C})(\mathrm{ii})$, (d)(2)(A) (2006) (requiring taxes on qualified payments to be paid at the occurrence of a taxable event for any qualified payments upon which payment of taxes on elections have been postponed through special elections); Treas. Reg. $\$ 25.2701-4(\mathrm{a})(3)$, (c)(1) (1992) (providing the formula by which to calculate the taxable amount of qualified payments upon the occurrence of a taxable event). 
qualified interest, to avoid unfavorable future transfer tax consequences of unpaid distributions. ${ }^{158}$

Likewise, the tax statutes allow trustees to elect to alter the incidence or the timing of income taxation. ${ }^{159}$ Finally, with the reinstatement of the estate tax for 2010 and 2011, Congress enacted an election-out option for decedents dying in $2010 .{ }^{160} \mathrm{An}$ executor may elect to apply the lower estate tax rate and higher exemption amount of the reinstated estate tax ${ }^{161}$ or to opt out of the estate tax and subject the estate assets to the carryover basis rules in Section 1022. ${ }^{162}$

\section{SUPERCHARGE THE PAT}

A PAT is a power of appointment trust that requires the same income disbursements to the surviving spouse as a QTIP trust: trust income payable at least annually. ${ }^{163}$ A PAT, however, also requires that the surviving spouse be given a power of appointment in favor of herself or her estate. Unlike the general power of appointment estate tax inclusion provision, ${ }^{164}$ the beneficiaries in a PAT are limited to the surviving spouse or her estate; with the inclusion statute, a general power of

158. See I.R.C. $\S 2701(\mathrm{~d})(1)-(3)$ (2006) (outlining the different tax treatment of qualified payments for election-in versus election-out).

159. See, e.g., I.R.C. $\$ \S 643(\mathrm{~g}), 645,663$ (b) (2006) (providing the option for tax payments to be made at different times at the option of the trustee).

160. See Tax Relief, Unemployment Insurance Reauthorization, and Job Creation Act of 2010, Pub. L. No. 111-312, § 301(c), 124 Stat. 3296, 3300 (to be codified at I.R.C. $\S \S 2001,2505$ (2006)) (allowing an executor the option of applying the older tax rate schedule to the estate of a decedent who died in 2010).

161. The 2010 legislation imposes a tax rate of $35 \%$ and a $\$ 5$ million exemption for those decedents dying in 2010. See Table 1, supra note 5 (calculating estate tax amounts collected by the federal government for tax returns filed in 2009); Tax Relief, Unemployment Insurance Reauthorization, and Job Creation Act of 2010, Pub. L. No. 111-312, § 302, 124 Stat. 3296, 3301 (to be codified at I.R.C. $\$ 2010$ (2006)) (defining the estate tax rates imposed by the 2010 legislation).

162. I.R.C. \& 1022 was enacted as part of the 2001 Act and contained rules for basis adjustments for decedent's dying after the then-intended estate tax repeal in 2010. The 2010 Act repealed this provision. Tax Relief, Unemployment Insurance Reauthorization, and Job Creation Act of 2010, Pub. L. No. 111-312, § 301(a), 124 Stat. 3296, 3300 (to be codified at I.R.C. $\S 1022$ (2006)) ("Each provision of law amended by subtitle $\mathrm{A}$ or $\mathrm{E}$ of title $\mathrm{V}$ of the Economic Growth and Tax Relief Reconciliation Act of 2001 is amended to read as such provision would read if such subtitle had never been enacted.").

163. See I.R.C. $\$ 2056(b)(5)$ (2006) (requiring that a PAT distribute income annually to qualify for the marital transfer deduction).

164. I.R.C. $\S 2041$ (b)(1) provides a definition of a general power of appointment that conforms to state law definitions. The marital deduction power of appointment in a PAT is more limited in that it can only benefit the surviving spouse or her estate. I.R.C. $\S 2056(\mathrm{~b})(5)(2006)$. 
appointment is defined as one exercisable in favor of the beneficiary, her estate, her creditors, or the creditors of her estate. Moreover, in a PAT, the surviving spouse's income payments may not be contingent, and the power of appointment must be exercisable by the surviving spouse "alone and in all events." 165

The PAT is considered owned by the surviving spouse because she not only has an income interest but also has a general power of appointment. While not equal to outright ownership, the PAT provides a rough equivalent. Yet, because of the flexibility of the QTIP, the PAT has all but disappeared as a viable option for spousal transfers. ${ }^{166}$

The PAT already shares two advantages with the QTIP trust: deferral of taxation and the use of the trust form. As trusts, both of these forms of the marital deduction constitute nonprobate property. ${ }^{167}$ They do not incur probate costs and they enjoy the privacy inherent in a trust. In addition, they both often utilize expert management for the assets in the trust.

Adding more of the accommodating advantages of the QTIP to the PAT would give the surviving spouse not only a quasi-equivalent of ownership but also the flexibility currently

165. Id.

166. The 2001 Act provided for an additional $\$ 3$ million step-up in basis for property passing outright to the surviving spouse or in a QTIP trust for individuals dying after December 31, 2009. See Economic Growth and Tax Relief Reconciliation Act of 2001, Pub. L. No. 107-16, § 542, 115 Stat. 38, 76-77 (2001) (codified at I.R.C. $\S 1022$ (2006)). The PAT was omitted from that list of "qualified spousal property." I.R.C. § 1022(c)(3) (2006). The 2010 Act repealed Section 1022 and the carryover basis rule for all but those decedents who died in 2010 and who elected to have no estate tax applied to them. Tax Relief, Unemployment Insurance Reauthorization, and Job Creation Act of 2010, Pub. L. No. 111-312, § 301(c), 124 Stat. 3296, 3300 (to be codified at I.R.C. $\$ \S 2001,2505$ (2006)). Despite repeal of the carryover basis statute, the dwindling use of the PAT was likely the reason to exclude PATs from the definition of I.R.C. $\S 1022$ spousal property interests. See Karen C. Burke \& Grayson M.P. McCouch, Estate Tax Repeal: Through the Looking Glass, 22 VA. TAX REv. 187, 206 (2002) (objecting to the additional $\$ 3$ million spousal exemption as "lack[ing] any convincing policy justification and rais[ing] serious issues of fairness"). Professors Burke and McCouch also point out that "[i]n effect, by retaining QTIP as the only viable alternative to an outright transfer, the 2001 Act encourages testators to provide the minimum qualifying interest-a life estate-for their surviving spouses while retaining full control over the ultimate disposition of the underlying property." Id. at 208. Moreover, Professors Burke and McCouch point out that the carryover basis rule under Section 1022, available to only QTIP trusts and outright gifts, primarily benefits the remainder beneficiary and not the spouse. Id. at 208-09 ("If the spouse receives only a life estate, there is no assurance that the underlying property will be sold during the spouse's life. In effect the QTIP provisions may be viewed as promoting marriage as a sort of tax shelter for the benefit of those who receive property after the death of the surviving spouse." (footnote omitted)).

167. See William M. MCGovern, Sheldon F. KuRTz \& David M. ENGLish, Wills, TRUSTS AND ESTATES 381-83 (4th ed. 2010) (explaining the historical evolution of trusts as legal instruments used to avoid probate court). 
available only to the QTIP trust. This proposal is intended to resuscitate the PAT form of the marital deduction. Also, this proposal only allows a marital deduction, and thus, only provides deferral for either outright gifts to a surviving spouse or transfers to a PAT.

Before the enactment of the QTIP provisions in 1981, the poorer spouse would have been given a testamentary power of appointment in the PAT. ${ }^{168}$ At the same time that the wealthy decedent's will created a PAT for her, the poorer spouse's will was drafted not exercising the power of appointment; then when the surviving spouse died, the property would pass to the takers in default as specified by the decedent in his will. ${ }^{169}$ It would not be an improvement to embellish the PAT with the adornments of the QTIP without changing this fundamental inadequacy of the PAT. Truly supercharging the PAT, therefore, requires amending the current PAT provisions to require a PAT to give the surviving spouse both an inter vivos power of appointment where she could access the property while she is alive as well as a testamentary power of appointment.

\section{BENEFITS OF A SUPER-CHARGED PAT}

The benefits of creating a super-charged PAT and of repealing the QTIP provisions are: (1) The government will receive needed money now for transfers from the decedent to third parties (that is, outside of the marital unit), such as to children from an earlier marriage; (2) The flexibility to make postmortem decisions will attach to the PAT, making the PAT an attractive format for the marital deduction for those who prefer to make a gratuitous transfer in trust; and (3) The conflicts inherent in a QTIP trust between the surviving spouse and children from decedent's earlier marriage or marriages will cease to exist.

The Article has already addressed the first two advantages of a super-charged PAT, so the rest of this section will concern the third benefit. One major disadvantage ${ }^{170}$ of a QTIP trust is

168. See Schain, supra note 46 , at 761-62 (differentiating the marital trust and tax options that existed before the enactment of the QTIP provision).

169. See Wanda Ellen Wakefield, Sufficiency of Exercise of Power Specifying That It Can Be Exercised Only By Specific or Direct Reference Thereto, 15 A.L.R. 4TH 810, 811-12 (1982) (explaining that trust property passes according to the deceased spouse's will when the surviving spouse fails to properly exercise a power of appointment clause during the surviving spouse's lifetime).

170. Another disadvantage of the QTIP is that because the QTIP trust does not provide the surviving spouse with much revenue, unless she has sufficient wealth of her own, she may be unable to make tax free gifts after decedent's death. 
the conflict of interest between the surviving spouse and the children from the decedent's earlier marriages. ${ }^{171}$ Using a PAT would eliminate that problem because only the surviving spouse, the surviving member of the marital unit, can be the beneficiary of a PAT. ${ }^{172}$ Administering a QTIP trust is difficult because the trustee must balance the interests of the income beneficiary with those of the remaindermen. ${ }^{173}$ Investments should neither favor income production nor appreciation. ${ }^{174}$ The trustee is a fiduciary who must adhere to the duties, among others, of loyalty and impartiality. ${ }^{175}$ But, with a PAT, there can be no third party beneficiaries and thus no conflicting split interests.

Further, it has been very difficult to avoid conflicts of interest where one estate planner prepared documents for both the spouses; that was especially true when the two spouses have uneven wealth or different beneficiaries. ${ }^{176}$ With a super-charged

171. Robert B. Wolf, Defeating the Duty to Disappoint Equally-The Total Return Trust, 32 ReAL PRoP. PROB. \& TR. J. 45, 83 (1997) ("One of the major reasons for this type of trust is concern about a second marriage, when the life beneficiary is a second spouse and the remaindermen are children by a prior marriage. In these situations, the potential conflict of interest is particularly strong between the life beneficiary and the remaindermen.").

172. See I.R.C. $\$ 2056(b)(5)$ (2006) (requiring a PAT to be exercisable by the surviving spouse alone).

173. Pruett, supra note 47, at 342 ("How much discretion does the trustee have? In most cases, the intent is probably to give primary consideration to the surviving spouse for his or her lifetime, even if that means encroaching on the principal that otherwise would pass to the descendants at the spouse's death. On the other hand, there may be circumstances, particularly in second (or third, or fourth) marriage situations, where the settlor's intent is that principal be used for the spouse's benefit only to the extent that trust income and/or other resources are insufficient for that purpose." (emphasis added)).

174. See Robert T. Willis, Jr., Coordinating Investment Planning with Tax Strategy for Estate and Trust Administration, 12 EST. PLAN. 226, 231 (1985) ("An investment strategy that maximizes yield for the current beneficiary will inherently reduce the growth potential (and therefore the inflation hedge) for the remaindermen, and vice versa. This dichotomy is exacerbated where the two classes of beneficiaries do not have harmonious objectives (e.g., in the case of a second spouse and children of a first spouse)."); Mark R. Gillett \& Katheleen R. Guzman, Managing Assets: The Oklahoma Uniform Principal and Income Act, 56 OKIA. L. REV. 1, 9-10 (2003) (discussing a trustee's duty of impartiality). Some have suggested a total return trust will alleviate this conflict. See Harrison, Lord \& Dillard, supra note 47, at 240 ("The Total Return Trust Act provides a means by which a trustee can balance the inherent tension between income beneficiaries, who generally prefer that a trustee invest in income producing assets, and remainder beneficiaries, who more often prefer investments that will create long-term capital appreciation that the remainder beneficiary will recognize at a later time.").

175. See RESTATEMENT (THIRD) OF TRUSTS $\$ 79$ (2007) (requiring a trustee to exercise impartiality between successive or multiple beneficiaries); UNIF. PRUDENT INVESTOR ACT $\S 6,7 B$ U.L.A. 36 (2006) (requiring a trustee to act impartially when a trust has multiple beneficiaries); DUKEMINIER, SITKOFF \& LINDGREEN, supra note 92, at 550 (detailing the various fiduciary duties of trustees).

176. Rather than separate, simultaneous representation of the couple by one attorney, one estate planner recommends separate representation for each spouse, in 
PAT, however, such problems would cease. To the extent that the couple wants to transfer property outright or in a super-charged PAT, the couple would only be entitled to a marital deduction where they in fact transferred the property to the surviving spouse. $^{177}$

\section{CONCLUSION}

This Article proposes to repeal the QTIP provisions in order to collect revenue now for transfers that are essentially transfers to third parties and not to the decedent's spouse. Because there are advantages of increased flexibility attendant to a QTIP as opposed to a PAT, this Article proposes to take those repealed QTIP benefits and attach them to the PAT, which would greatly enhance that marital deduction trust form. A super-charged PAT would thereby be able to preserve the decedent's GST tax exemption (like a reverse QTIP), create a decedent's by-pass trust by allowing a PAT (or a partial PAT) "election-out," and result in states enacting a decedent's state-only PAT marital deduction. The super-charged PAT would provide for much desired postmortem tax planning without the complex and strict requirements of a disclaimer. Moreover, the new PAT would eliminate conflicts of interest and fiduciary problems inherent in the QTIP form of the marital deduction. Lastly, by repealing the QTIP provisions and by supercharging the PAT, the marital deduction would truly be a marital deduction and not a third party beneficiary tax deferral device.

order that each spouse is able to more freely plan his or her own estate. See Teresa Stanton Collett, And the Two Shall Become as One... Until the Lawyers Are Done, 7 NOTRE DAME J.L. ETHICS \& PUB. POL'Y 101, 102-04 (1993) (identifying potential conflicts of interest that may arise when a lawyer represents both husband and wife in estate planning); Gerald P. Johnston, An Ethical Analysis of Common Estate Planning Practices-Is Good Business Bad Ethics?, 45 OHIO ST. L.J. 57, 60 \& n.4 (1984) (examining potential conflicts of interest that may arise when a lawyer drafts wills for both husband and wife).

177. See I.R.C. $\$ 2056(\mathrm{a})$, (b)(5), (b)(7)(A)-(B) (2006) (listing the QTIP, outright property transfer, and PAT as property transfer instruments that presently qualify for the marital deduction). 
